\begin{tabular}{|c|l|}
\hline Title & Transformation of Bulk Pd to Pd Cations in Small-Pore CHA Zeolites Facilitated by NO \\
\hline Author(s) & $\begin{array}{l}\text { Yasumura, Shunsaku; Ide, Hajime; Ueda, Taihei; Jing, Y uan; Liu, Chong; Kon, Kenichi; Toy ao, Takashi; Maeno, Zen; } \\
\text { Shimizu, Ken-ichi }\end{array}$ \\
\hline Citation & $\begin{array}{l}\text { JACS Au, 1(2), 201-211 } \\
\text { https://doi.org/10.1021/acsau.0c00112 }\end{array}$ \\
\hline Issue Date & 2021-01-13 \\
\hline Doc URL & http://hdl.handle.net/2115/81042 \\
\hline Rights(URL) & https://reativecommons.org/icenses/by-nc-nd/4.0/ \\
\hline Type & article \\
\hline File Information & jacsau.Oc00112.pdf \\
\hline
\end{tabular}

Instructions for use 


\title{
Transformation of Bulk Pd to Pd Cations in Small-Pore CHA Zeolites Facilitated by NO
}

\author{
Shunsaku Yasumura, Hajime Ide, Taihei Ueda, Yuan Jing, Chong Liu, Kenichi Kon, Takashi Toyao, \\ Zen Maeno,* and Ken-ichi Shimizu*
}

Cite This: JACS Au 2021, 1, 201-211

Read Online

\section{ACCESS

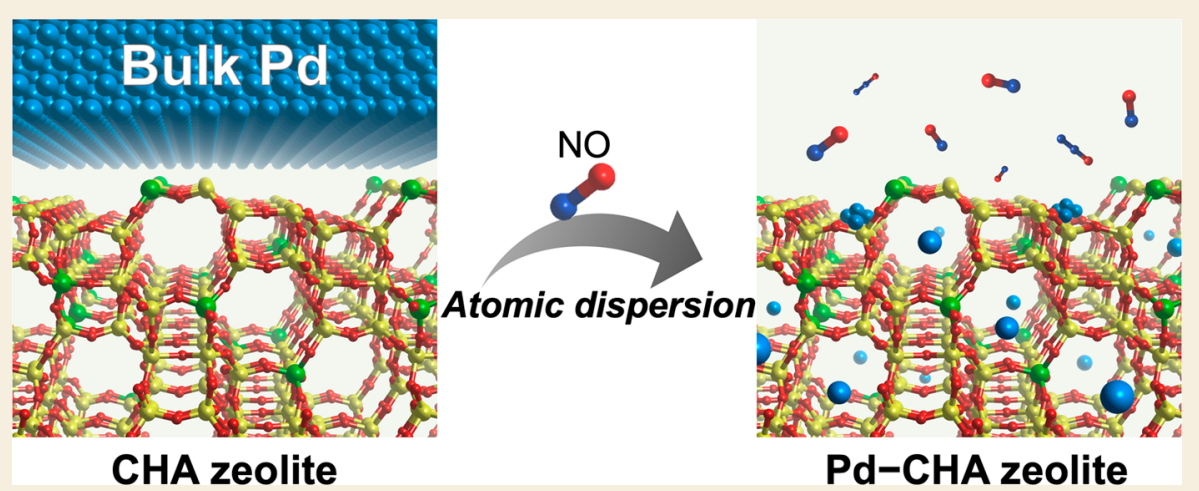

ABSTRACT: Atomic dispersion of metal species has attracted attention as a unique phenomenon that affects adsorption properties and catalytic activities and that can be used to design so-called single atom materials. In this work, we describe atomic dispersion of bulk Pd into small pores of CHA zeolites. Under $4 \% \mathrm{NO}$ flow at $600{ }^{\circ} \mathrm{C}$, bulk Pd metal on the outside of CHA zeolites effectively disperses, affording $\mathrm{Pd}^{2+}$ cations on $\mathrm{Al}$ sites with concomitant formation of $\mathrm{N}_{2} \mathrm{O}$, as revealed by microscopic and spectroscopic characterizations combined with mass spectroscopy. In the present method, even commercially available submicrosized Pd black can be used as a Pd source, and importantly, $4.1 \mathrm{wt} \%$ of atomic $\mathrm{Pd}^{2+}$ cations, which is the highest loading amount reported so far, can be introduced into CHA zeolites. The structural evolution of bulk Pd metal is also investigated by in situ X-ray absorption spectroscopy (XAS) and diffuse reflectance infrared Fourier transform spectroscopy (DRIFTS), as well as ab initio thermodynamic analysis using density functional theory (DFT) calculations.

KEIWORDS: atomic dispersion, small-pore zeolites, palladium, in situ spectroscopy, ab initio thermodynamics

\section{INTRODUCTION}

Supported metal species have been widely utilized as heterogeneous catalysts and adsorbers. ${ }^{1-4}$ The morphology and oxidation state of immobilized metal species dynamically change with temperature and atmosphere. ${ }^{5-20}$ Generally, exposure to high temperature induces aggregation of metal species to form larger particles via particle coalescence and atomic ripening. Particle coalescence involves temperatureinduced movement of metal nanoparticles, while atomic ripening occurs via movement of atomic species on supports or in vapor phase. As an opposite phenomenon, atomic dispersion of metal species occurs when mobile atomic species are trapped by supports. ${ }^{21-39}$ Several microscopic and spectroscopic studies on atomic dispersion have appeared recently, investigating structural evolution under various reaction conditions and their effects on catalytic and adsorption properties. ${ }^{28,33-38}$ Atomic dispersion also has the potential to be applied to atomically dispersed materials as well as catalyst regeneration processes, and several examples have appeared. ${ }^{2}$

Aluminosilicate zeolites are promising oxide supports that anchor atomic metal species as cations due to their cation exchange abilities, as well as ubiquitousness of constituent elements $(\mathrm{Si}, \mathrm{Al}, \mathrm{O})$ with commercial availability. In the case of divalent cations, such as $\mathrm{Pd}^{2+}$, paired $\mathrm{Al}$ sites in threedimensional zeolite frameworks serve as anchoring sites, stabilizing through electrostatic interactions. Among them, eight-membered ring zeolites, such as $\mathrm{CHA}$, have high potential to suppress aggregation of metal cations under reaction conditions because of their small pore sizes $(3.8 \AA \times$

Received: December 14, 2020

Published: January 13, 2021 

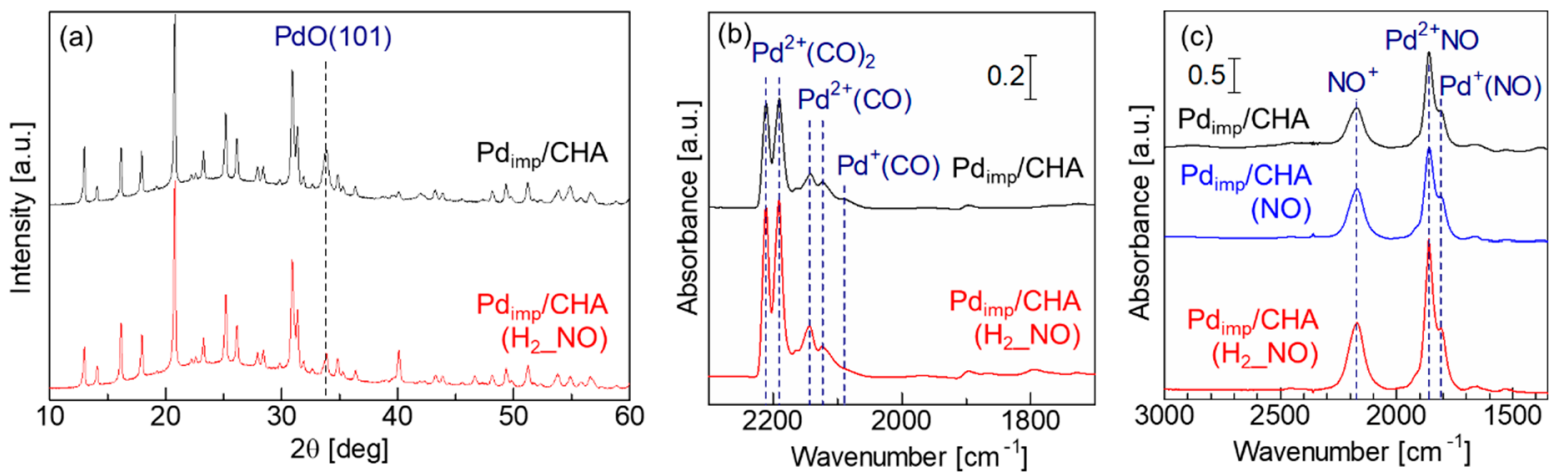

Figure 1. (a) XRD patterns and FTIR spectroscopy of (b) CO and (c) NO adsorption experiments for a series of $\mathrm{Pd}_{\mathrm{imp}} / \mathrm{CHA}$. The CO adsorption experiment was conducted at room temperature under $0.1 \% \mathrm{CO} / \mathrm{He}$ flow, followed by a $\mathrm{He}$ purge, while the NO adsorption experiment was investigated at $100{ }^{\circ} \mathrm{C}$ under $0.1 \% \mathrm{NO} / \mathrm{He}$ flow. Prior to adsorption experiments, the sample was treated by $10 \% \mathrm{O}_{2} / \mathrm{He}$ to remove $\mathrm{NO}$ adsorbed during atomic dispersion. Detailed procedures are described in the SI.

$3.8 \AA$ ) and superior stability toward hydrothermal conditions compared to medium- and large-pore zeolites. ${ }^{40-44}$ Despite the fact that several metal-exchanged $\mathrm{CHA}$ zeolites, such as $\mathrm{Cu}$ $\mathrm{CHA}$, can be synthesized by conventional aqueous-phase ion exchange methods, loading Pd cations into CHA zeolites is difficult owing to strong water solvation of cations, which are too bulky to access the small pores. For example, Szanyi and co-workers loaded Pd cations into several zeolites via ion exchange in aqueous solution for use as passive $\mathrm{NO}_{x}$ adsorbers (PNAs), where isolated $\mathrm{Pd}$ cations are responsible for $\mathrm{NO}$ adsorption and aggregated $\mathrm{PdO}$ particles are ineffective. ${ }^{45-47}$ Very small amounts of $\mathrm{Pd}(1.4 \%)$ were exchanged with cations in CHA in aqueous solution at Pd loading amounts of $0.5 \mathrm{wt}$ $\%$, while almost all the Pd (ca. 75\%) was immobilized at ionexchange sites in BEA and ZSM-5 under similar Pd loading amounts and $\mathrm{Si} / \mathrm{Al}$ ratios of zeolites. ${ }^{48} \mathrm{Kim}$ and co-workers prepared Pd-modified CHA by incipient wetness impregnation and examined hydrothermal aging treatments at $700-750{ }^{\circ} \mathrm{C}$ to increase the number of active $\mathrm{Pd}$ cations for $\mathrm{NO}$ adsorption. ${ }^{38}$ However, bulk PdO was the main Pd species, even after treatment, as confirmed by X-ray diffraction (XRD) and X-ray absorption spectroscopy (XAS) measurements. Although Pd cation loading (1-3.5 wt \%) has been recently achieved via a modified aqueous-phase ion exchange method by the group of Szanyi, ${ }^{40}$ the development of effective methods to load Pd cations in small-pore zeolites still needs to be addressed.

In this study, we describe atomic dispersion of bulk Pd into $\mathrm{CHA}$ zeolites for solid-state synthesis of Pd-exchanged CHA. Bulk Pd metal outside the CHA zeolites is transformed into $\mathrm{Pd}^{2+}$ cations on zeolite anionic sites under $\mathrm{NO}$ flow at $600{ }^{\circ} \mathrm{C}$. Preparation of Pd-exchanged CHA zeolites from commercially available Pd black and CHA zeolites was also achieved.

Although redispersion of aggregated metal clusters in medium- and large-pore zeolites ${ }^{21,22,30,32,37,39}$ and the transport of metal cations/nanoparticles from the outside of CHA zeolites have been reported, ${ }^{25,49}$ atomic dispersion of bulk Pd from outside into small-pore zeolites has not yet been reported. Microscopic (scanning electron microscopy (SEM) and scanning transmission electron microscopy (STEM)) and spectroscopic (XRD, XAS, and Fourier transform infrared (FTIR)) characterizations revealed that atomic $\mathrm{Pd}^{2+}$ cations were mainly formed, and the loading amount of $\mathrm{Pd}^{2+}$ cations reached ca. 4 wt \%. In situ spectroscopic studies (XAS and diffuse reflectance infrared Fourier transform spectroscopy
(DRIFTS)) and $a b$ initio thermodynamics analysis using density functional theory (DFT) were also conducted to gain insight into atomic dispersion of bulk Pd in CHA zeolites. Furthermore, a plausible mechanism was theoretically studied to discuss the reason for the necessity of high reaction temperature.

\section{EXPERIMENTAL SECTION}

Pd-modified CHA zeolites were prepared through impregnation of $\mathrm{Pd}\left(\mathrm{NH}_{3}\right)_{2}\left(\mathrm{NO}_{3}\right)_{2}$ on CHA $\left(\mathrm{NH}_{4}\right.$-type, Tosoh, $\left.\mathrm{SiO}_{2} / \mathrm{Al}_{2} \mathrm{O}_{3}=13.7\right)$, followed by calcination in $10 \% \mathrm{O}_{2} / \mathrm{He}$ at $600{ }^{\circ} \mathrm{C}$ (denoted as $\mathrm{Pd}_{\text {imp }}$ ) CHA). Subsequently, $\mathrm{Pd}_{\text {imp }} / \mathrm{CHA}$ was treated by $0.5 \% \mathrm{H}_{2} / \mathrm{He}$ flow at $500{ }^{\circ} \mathrm{C}$ and then exposed to $4 \% \mathrm{NO} / \mathrm{He}$ flow at $600{ }^{\circ} \mathrm{C}$ to load $\mathrm{Pd}^{2+}$ cations by atomic dispersion (denoted as $\mathrm{Pd}_{\text {imp }} / \mathrm{CHA}\left(\mathrm{H}_{2} \_\mathrm{NO}\right)$ ). The total amount of $\mathrm{Pd}$ was determined based on the amounts of $\mathrm{Pd}$ precursor and CHA zeolites. The atomic dispersion reaction was conducted using a self-supported pellet in a flow-type quartz cell connected to a flow reaction system. XRD, SEM, STEM, and ex situ XAS were conducted after exposing the samples to air. CO, NO, and $\mathrm{NH}_{3}$ adsorption experiments, with monitoring by FTIR spectroscopy, were conducted without exposure to air. Prior to adsorption experiments, the obtained sample was treated under $\mathrm{O}_{2}$ at $600{ }^{\circ} \mathrm{C}$ to remove $\mathrm{NO}$ adsorbed during atomic dispersion reactions. The physical mixture of Pd black and $\mathrm{CHA}$ zeolite ( $\mathrm{Pd}+\mathrm{CHA})$ was obtained by mixing commercially available Pd black (Nakalai Tesque, Ltd.) and CHA zeolite in gate mortar. The in situ XAS measurement was conducted on a flow-type quartz cell with a gas mixing system in a BL14B2, SPring-8 (JASRI, Proposal No. 2019B1686). In situ DRIFTS was performed using a FTIR spectrometer equipped with a diffuse reflectance cell. DFT calculations were performed with a periodic boundary condition under the Kohn-Sham formulation with the Vienna ab initio simulation package (VASP).$^{50,51}$ The generalized gradient approximated Perdew-Burke-Ernzerhof (GGA-PBE) functional was applied for electron exchange-correlation. XANES spectra were simulated for the DFT-optimized structures using the FDMNES software. $^{52,53}$ More detail on the experimental methodology is described in the Supporting Information (SI).

\section{RESULTS AND DISCUSSION}

\subsection{Atomic Dispersion of Bulk Pd in Pd-Modified CHA Prepared by Impregnation Methods}

The XRD pattern of $\mathrm{Pd}_{\text {imp }} / \mathrm{CHA}$ (Pd: 5.4 wt \%) exhibited typical diffraction patterns of $\mathrm{CHA}$ zeolite with a peak derived from $\mathrm{PdO}(101)$ at $2 \theta=33.7^{\circ}$ (Figure 1a). The FTIR spectrum from the $\mathrm{CO}$ adsorption experiment showed peaks resulting from stretching vibrations of $\mathrm{C}=\mathrm{O}(\nu(\mathrm{C}=\mathrm{O}))$ from CO-coordinated Pd cations, such as $\mathrm{Pd}^{2+}(\mathrm{CO})_{2}, \mathrm{Pd}^{2+}(\mathrm{CO})$, 

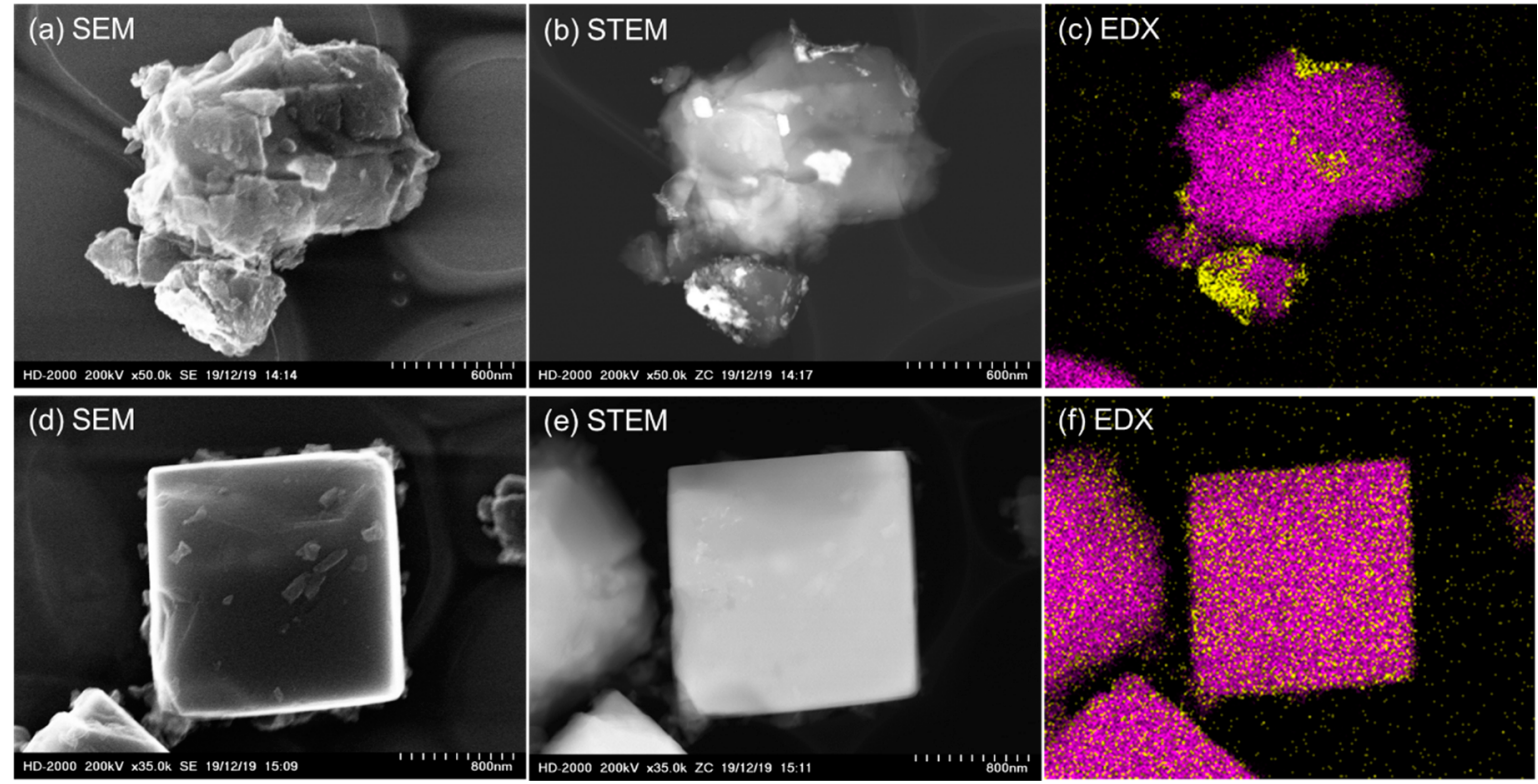

Figure 2. SEM (a and d), high-angle annular dark field STEM images (b and e), and elemental mapping of Pd (yellow) and Si (purple), obtained by EDX spectroscopy $(\mathrm{c}$ and $\mathrm{f})$, for $\mathrm{Pd}_{\mathrm{imp}} / \mathrm{CHA}(\mathrm{a}-\mathrm{c})$ and $\mathrm{Pd}_{\mathrm{imp}} / \mathrm{CHA}\left(\mathrm{H}_{2} \_\mathrm{NO}\right)(\mathrm{d}-\mathrm{f})$.

and $\mathrm{Pd}^{+}(\mathrm{CO})$, around $2220-2100 \mathrm{~cm}^{-1}$ (Figure $\left.1 \mathrm{~b}\right){ }^{54}$ Note that the group of Szanyi has recently revealed that the main two peaks around $2200 \mathrm{~cm}^{-1}$, which had been assigned as $\mathrm{Pd}^{3+}(\mathrm{CO})_{2},{ }^{22,55}$ are derived from highly positive $\mathrm{Pd}^{2+}(\mathrm{CO})_{2}$ ions by experimental and theoretical approaches. ${ }^{54,56} \mathrm{XRD}$ and FTIR spectroscopy from the $\mathrm{CO}$ adsorption experiment indicated that both bulk $\mathrm{PdO}$ and atomic Pd cations exist after impregnation and calcination. The coexistence of bulk $\mathrm{PdO}$ and atomic Pd cations is further supported by SEM and STEM results, as well as energy dispersed X-ray (EDX) spectroscopy (Figure 2a-c).

To investigate the atomic dispersion of bulk $\mathrm{Pd}$ on the outside of $\mathrm{CHA}$ zeolite under oxidative conditions, $\mathrm{Pd}_{\mathrm{imp}} /$ CHA was pretreated with $0.5 \% \mathrm{H}_{2} / \mathrm{He}$ at $500{ }^{\circ} \mathrm{C}$ for $30 \mathrm{~min}$ and, then, exposed to $4 \% \mathrm{NO} / \mathrm{He}$ flow at $600{ }^{\circ} \mathrm{C}$ for $30 \mathrm{~min}$ $\left(\mathrm{Pd}_{\mathrm{imp}} / \mathrm{CHA}\left(\mathrm{H}_{2} \mathrm{NO}\right)\right)$. In the $\mathrm{XRD}$ pattern of $\mathrm{Pd}_{\mathrm{imp}} /$ $\mathrm{CHA}\left(\mathrm{H}_{2} \mathrm{NO}\right)$, the peak intensity derived from PdO (101) considerably decreased, while the diffraction pattern of $\mathrm{CHA}$ zeolite was retained (Figure 1a, the enlarged view (Figure S1) is shown in the SI). The FTIR spectrum collected from the $\mathrm{CO}$ adsorption experiment showed that absorptions derived from $\mathrm{CO}$ coordinated to $\mathrm{Pd}$ cations increased and peaks derived from $\mathrm{CO}$ adsorbed on the metallic Pd surface were scarce (Figure 1b). STEM and EDX spectroscopy (Figure 2df) showed the absence of aggregated Pd species. Together, these results suggest that the outside of bulk Pd was atomically dispersed into CHA zeolite by $\mathrm{H}_{2}$ and $\mathrm{NO}$ treatment.

FTIR spectroscopy of the NO adsorption experiment was further conducted. One NO molecule is known to adsorb on one $\mathrm{Pd}^{n+}$ cation in zeolites, which exhibits a strong $\nu(\mathrm{N}-\mathrm{O})$ absorption band around $1800-1900 \mathrm{~cm}^{-1}$. We estimated the amount of NO adsorbed based on peak areas with the absorption coefficient value (see SI) and, then, calculated the molar ratio of adsorbed $\mathrm{NO}$ and total $\mathrm{Pd}$ in the samples (hereinafter denoted as $\mathrm{NO} / \mathrm{Pd}$, theoretical maximum is $100 \%)$ as an index of $\mathrm{Pd}$ dispersion. Prior to NO adsorption, the background spectrum was obtained after the $10 \% \mathrm{O}_{2} / \mathrm{He}$ treatment at $600{ }^{\circ} \mathrm{C}$, followed by the He purge at $100{ }^{\circ} \mathrm{C}$. The adsorption experiment was conducted under $0.1 \% \mathrm{NO} / \mathrm{He}$ flow at $100{ }^{\circ} \mathrm{C}$, while continuously recording IR spectra. The IR spectra for $\mathrm{Pd}_{\text {imp }} / \mathrm{CHA}$ and $\mathrm{Pd}_{\text {imp }} / \mathrm{CHA}\left(\mathrm{H}_{2} \mathrm{NO}\right.$ ) (Figure 1c) showed strong peaks at $1861 \mathrm{~cm}^{-1}$, arising from $\nu(\mathrm{N}-\mathrm{O})$ of $\mathrm{Pd}^{2+}(\mathrm{NO})$, with shoulder peaks around $1810 \mathrm{~cm}^{-1}$, assignable to $\mathrm{Pd}^{+}(\mathrm{NO}){ }^{40}$ Note that the assignment of $\mathrm{NO}$ was well supported by the DFT studies in the previous paper. ${ }^{54}$ The absorbance for $\mathrm{Pd}_{\mathrm{imp}} / \mathrm{CHA}\left(\mathrm{H}_{2} \mathrm{NO}\right)$ was much higher than for $\mathrm{Pd}_{\text {imp }} / \mathrm{CHA}$; $\mathrm{NO} / \mathrm{Pd}$ increased from $32.6 \%$ to $76.1 \%$ following $\mathrm{H}_{2}$ and $\mathrm{NO}$ treatment. The $\mathrm{NO}$ adsorption experiment showed that mainly $\mathrm{Pd}^{2+}$ cations formed. When $\mathrm{Pd}_{\text {imp }} / \mathrm{CHA}$ was directly treated with $\mathrm{NO}$ without $\mathrm{H}_{2}$ reduction $\left(\mathrm{Pd}_{\text {imp }} / \mathrm{CHA}(\mathrm{NO})\right), \mathrm{NO} / \mathrm{Pd}$ was calculated to be $49.1 \%$, which was lower compared to $\mathrm{Pd}_{\text {imp }} / \mathrm{CHA}\left(\mathrm{H}_{2} \_\mathrm{NO}\right)$. The metallic state is essential for efficient atomic dispersion of outside bulk Pd species into small-pore CHA zeolites.

The effect of loading amounts $(1,5.4$, and $6.8 \mathrm{wt} \%)$ on $\mathrm{Pd}$ dispersion was also investigated (The FTIR spectra are shown in Figure S2 in the SI). NO/Pd values were nearly the same for 1 and 5.4 wt \% $(78.7 \%$ and $76.1 \%)$, while the increase in loading amount to $6.8 \mathrm{wt} \%$ resulted in a decrease of the $\mathrm{NO} /$ $\mathrm{Pd}$ value to $63.3 \%$. Based on the loading amount (5.4 wt \%) and $\mathrm{NO} / \mathrm{Pd}$ value, the contribution of $\mathrm{Pd}^{2+}$ cations was calculated to be $4.1 \mathrm{wt} \%$. Considering that one $\mathrm{Pd}^{2+}$ cation is anchored by paired $\mathrm{Al}$ sites, the required amount of $\mathrm{Al}$ sites to stabilize 4.1 wt $\%$ of $\mathrm{Pd}^{2+}$ cations are theoretically estimated to be $0.76 \mathrm{mmol} / \mathrm{g}$, which is lower than $50 \%$ of the total $\mathrm{Al}$ content of $\mathrm{CHA}\left(\mathrm{SiO}_{2} / \mathrm{Al}_{2} \mathrm{O}_{3}=13.7\right)(2.1 \mathrm{mmol} / \mathrm{g})$. Therefore, we can consider that all the Pd cations exist on Al sites.

To support the formation of Pd cations in CHA zeolites, an ex situ XAS measurement was carried out. The normalized XAS spectrum of $\mathrm{Pd}_{\text {imp }} / \mathrm{CHA}\left(\mathrm{H}_{2} \mathrm{NO}\right)$ after $\mathrm{O}_{2}$ treatment exhibited an absorption edge similar to that of $\mathrm{PdO}$, rather than Pd black (Figure 3a). In the FT of the extended X-ray absorption fine structure (EXAFS) spectra of $\mathrm{Pd}_{\mathrm{imp}} / \mathrm{CHA}$ and $\mathrm{O}_{2}$-treated $\mathrm{Pd}_{\text {imp }} / \mathrm{CHA}\left(\mathrm{H}_{2} \mathrm{NO}\right)$, the peak derived from the $\mathrm{Pd}-(\mathrm{O})-\mathrm{Pd}$ shell drastically decreased in intensity by $\mathrm{H}_{2}$ and NO treatment (Figure $3 \mathrm{~b}$ ). The coordination number of the $\mathrm{Pd}-\mathrm{O}$ shell for $\mathrm{O}_{2}$-treated $\mathrm{Pd}_{\mathrm{imp}} / \mathrm{CHA}\left(\mathrm{H}_{2} \_\mathrm{NO}\right)$ was 

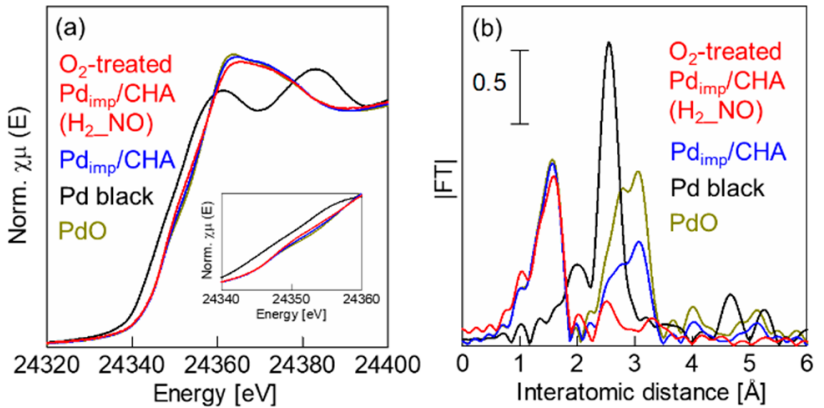

Figure 3. (a) Ex situ XANES and (b) FT of EXAFS spectra of $\mathrm{Pd}_{\text {imp }} /$ $\mathrm{CHA}, \mathrm{O}_{2}$-treated $\mathrm{Pd}_{\mathrm{imp}} / \mathrm{CHA}\left(\mathrm{H}_{2} \mathrm{NO}\right)$, and reference samples (Pd Black and $\mathrm{PdO}$ ) obtained under ambient conditions (air at room temperature).

estimated as 3.5 (Table S1). These results are consistent with the formation of Pd cations.

Furthermore, FTIR spectroscopy of $\mathrm{NH}_{3}$ adsorption was conducted to investigate the coordination of Pd cations for the $\mathrm{O}_{2}$-treated $\mathrm{Pd}_{\mathrm{imp}} / \mathrm{CHA}\left(\mathrm{H}_{2}\right.$ NO) with different $\mathrm{Pd}$ loading amounts $(1,3$, and $5.4 \mathrm{wt} \%)$. The spectrum of $\mathrm{H}-\mathrm{CHA}$ after $\mathrm{NH}_{3}$ adsorption exhibited a strong absorption band arising from $\mathrm{NH}_{3}$ on protons at zeolite Al sites (Figure $4 \mathrm{a}$ ). ${ }^{57}$ The
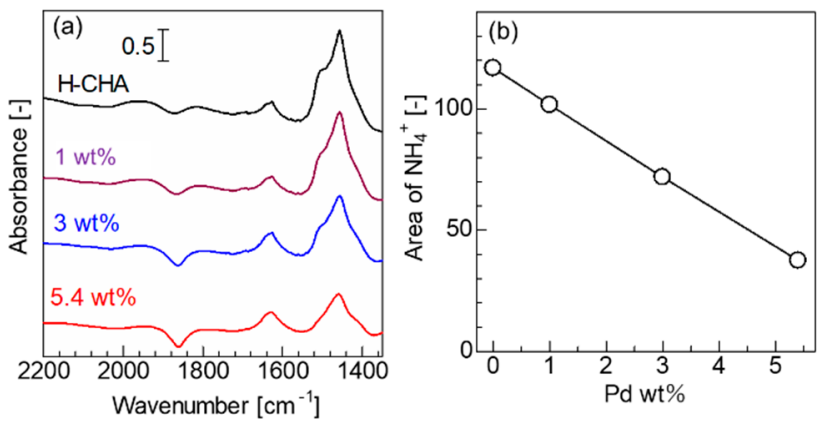

Figure 4. (a) FTIR spectra of $\mathrm{NH}_{3}$ adsorption for $\mathrm{H}-\mathrm{CHA}$ and $\mathrm{O}_{2}$ treated $\mathrm{Pd}_{\text {imp }} / \mathrm{CHA}\left(\mathrm{H}_{2} \_\mathrm{NO}\right)$ with different Pd loading amounts $(1$, 3 , and $5.4 \mathrm{wt} \%)$. The adsorption experiment was conducted at $50{ }^{\circ} \mathrm{C}$ under $1 \% \mathrm{NH}_{3} / \mathrm{He}$ flow, followed by a $\mathrm{He}$ purge. Prior to the adsorption experiments, the sample was treated by He flow at $600{ }^{\circ} \mathrm{C}$. The detailed procedures are described in the SI. (b) Relationship between the peak area of the absorption band, derived from $\mathrm{NH}_{4}{ }^{+}$and Pd loading amount.

peak area of this band monotonically decreased with increasing loading amounts from 1 to 5.4 wt \% (Figure $4 \mathrm{a}$ and $4 \mathrm{~b}$ ), indicating $\mathrm{Pd}^{2+}$ cations were immobilized at $\mathrm{Al}$ sites in $\mathrm{CHA}$ zeolites. To support this consideration, $\mathrm{SiO}_{2}$-supported $\mathrm{Pd}$ $\left(\mathrm{Pd}_{\mathrm{imp}} / \mathrm{SiO}_{2}, 5.4\right.$ wt \%) was prepared and, then, treated with $0.5 \% \mathrm{H}_{2} / \mathrm{He}$ flow, followed by $4 \% \mathrm{NO} / \mathrm{He}$ treatment, in a similar manner. However, the $\mathrm{NO}$ adsorbed on atomic $\mathrm{Pd}$ cations was hardly detected, and $\mathrm{NO} / \mathrm{Pd}$ was about $1 \%$ (Figure S3), showing that anchoring sites are necessary for atomic dispersion.

3.2. Preparation of Pd-Exchanged CHA from Pd Black and CHA Zeolites

Encouraged by the above results, we envisioned that NOinduced atomic dispersion of outside bulk Pd can be utilized for a physical mixture of Pd black and CHA zeolites ( $\mathrm{Pd}$ + CHA, Pd: 5.4 wt \%). This solid-state reaction would be another preparation method of Pd-exchanged CHA zeolites with high Pd cation loading amounts. Submicrosized bulk Pd and microsized cubic zeolites were observed by field-emissionand backscattered-electron SEM (FE- and BSE-SEM) and EDX mapping (Figure 5a). Pd+CHA was pretreated under $0.5 \% \mathrm{H}_{2} / \mathrm{He}$ flow at $300{ }^{\circ} \mathrm{C}$, followed by treatment with $4 \%$ $\mathrm{NO} / \mathrm{He}$ flow at $600{ }^{\circ} \mathrm{C}$ for $2 \mathrm{~h}(\mathrm{Pd}+\mathrm{CHA}(\mathrm{NO}))$. SEM micrographs with EDX mapping of $\mathrm{Pd}+\mathrm{CHA}(\mathrm{NO})$ revealed that highly dispersed $\mathrm{Pd}$ species were immobilized in $\mathrm{CHA}$ zeolites, whereas submicrosized Pd species were hardly observed (Figure 5b). In the XRD spectra, the diffraction peak derived from $\operatorname{Pd}(111)$, around $2 \theta=\mathrm{ca} .40^{\circ}$, disappeared after NO treatment, while the diffraction pattern of $\mathrm{CHA}$ zeolite was maintained (Figure 6a).

Atomic dispersion of Pd black was evaluated by FTIR spectroscopy of $\mathrm{CO}$ and $\mathrm{NO}$ adsorption experiments for $\mathrm{Pd}$ $+\mathrm{CHA}$ and $\mathrm{Pd}+\mathrm{CHA}(\mathrm{NO})$. The FTIR spectrum from the CO adsorption experiment revealed the formation of atomic $\mathrm{Pd}$ cations by NO treatment. The spectrum of $\mathrm{NO}$ adsorption showed that the $\mathrm{NO} / \mathrm{Pd}$ value significantly increased from $9.9 \%$ to $76.3 \%$. The results in the $\mathrm{CO}$ and $\mathrm{NO}$ adsorption experiments for $\mathrm{Pd}+\mathrm{CHA}(\mathrm{NO})$ and $\mathrm{Pd}_{\text {imp }} / \mathrm{CHA}\left(\mathrm{H}_{2} \_\mathrm{NO}\right)$ are almost the same. As control experiments, $\mathrm{O}_{2}$ and $\mathrm{CO}$ were used instead of $\mathrm{NO}$ for treatment of $\mathrm{Pd}+\mathrm{CHA}\left(\mathrm{Pd}+\mathrm{CHA}\left(\mathrm{O}_{2}\right)\right.$ and $\mathrm{Pd}+\mathrm{CHA}(\mathrm{CO}))$, and then, their $\mathrm{Pd}$ dispersions were evaluated by $\mathrm{NO}$ adsorption experiments. The resulting $\mathrm{NO} /$ $\mathrm{Pd}$ values were $21.4 \%$ and $15.4 \%$, respectively. NO treatment was most effective for atomic dispersion of bulk Pd. The recent study on preparation of Pd-loaded CHA zeolites via modified ion-exchange method reported by Szanyi has achieved a complete atomic dispersion $(\mathrm{NO} / \mathrm{Pd}=100 \%)$ for $1-1.9 \mathrm{wt} \%$ of total Pd loading whereas the increase of Pd loading amount resulted in the decrease of atomic dispersion (NO/Pd $=90 \%$ and $70 \%$ for 3 and 5 wt \% of Pd loading, respectively). ${ }^{40}$ In our case using NO-facilitated atomic dispersion of Pd black, a comparable NO/Pd (76.1\%) was obtained for 5.4 wt \% of Pd loading although complete atomic dispersion was not achieved for lower Pd loading amount $(\mathrm{NO} / \mathrm{Pd}=91.2 \%$ and $89.5 \%$ for 1 and 3 wt \% of Pd loading, respectively. See below). The literature comparison of loading amount of $\mathrm{Pd}^{2+}$ cations is summarized in Table S2 in the SI.

\subsection{Atomic Dispersion of Bulk Pd into Other Zeolites with Different Framework Types}

The dispersion of Pd nanoparticles (NPs) in zeolites under oxidative reaction conditions has been studied by several research groups. ${ }^{21,22,32}$ Primet and co-workers first demonstrated the dispersion of small Pd NPs in zeolites to afford $\mathrm{Pd}^{2+}$ cations. ${ }^{21}$ They prepared $\mathrm{Pd}^{2+}$-exchanged $\mathrm{Y}$ zeolites by an aqueous phase ion exchange method followed by the reduction treatment by $\mathrm{H}_{2}$, affording the $2 \mathrm{~nm} \mathrm{Pd}(0)$ NPs occluded in the zeolites. Subsequently, the oxidative redispersion of $\mathrm{Pd}$ $\mathrm{NPs}$ in the zeolite cages was conducted by $\mathrm{NO}$ at room temperature. Bell and Okumura independently reported the redispersion of small Pd NPs in MFI zeolites obtained by the $\mathrm{H}_{2}$ reduction of $\mathrm{Pd}^{2+}$-exchanged MFI zeolites in similar manners. $^{22,32}$ The redispersion of aggregated $\mathrm{Pd}$ by $\mathrm{NO}$ treatment has also been extensively utilized in the industry for catalyst regeneration. ${ }^{30}$ However, the oxidative dispersion of bulk Pd, such as commercially available Pd black, was not investigated in the aforementioned studies.

To investigate the effect of zeolite framework types and the difference of small Pd NPs and bulk Pd in atomic dispersion, the reaction of a physical mixture of Pd black (Pd: 1 wt \%) and 
(a) $\mathrm{Pd}+\mathrm{CHA}$
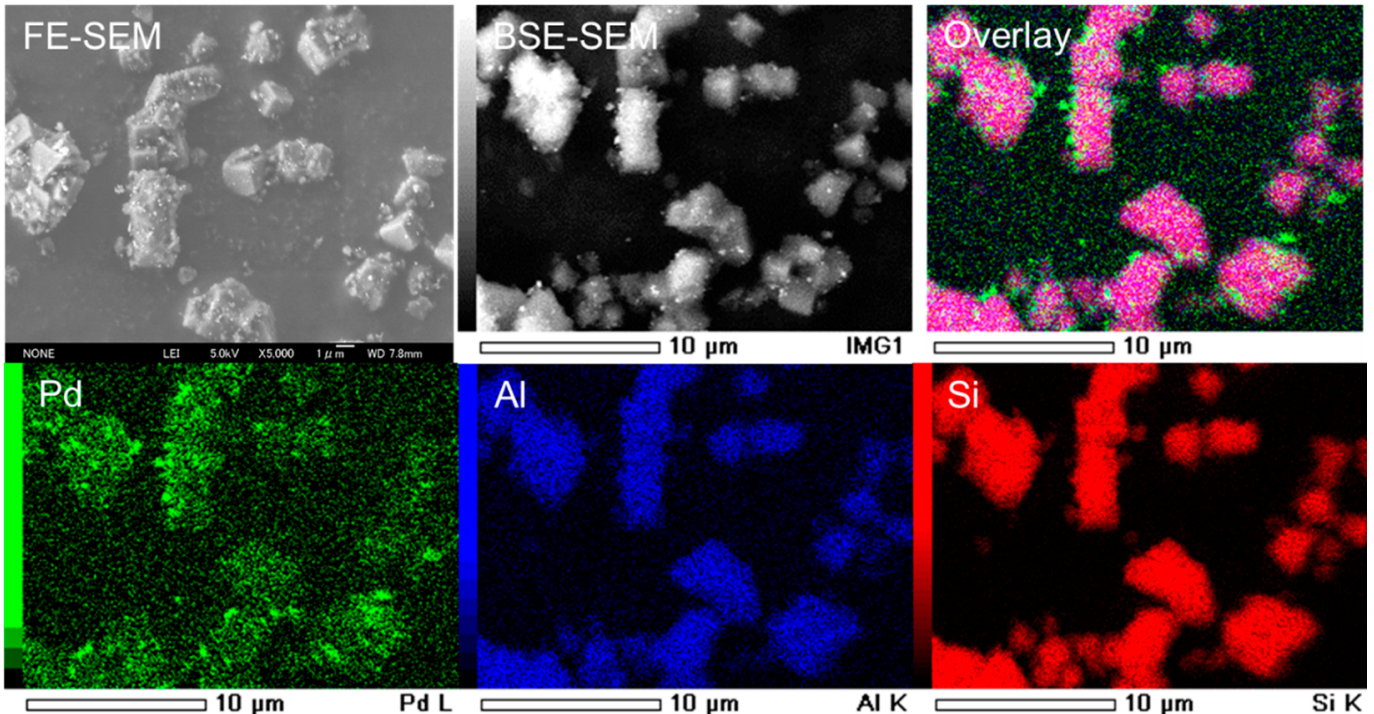

(b) $\mathrm{Pd}+\mathrm{CHA}(\mathrm{NO})$
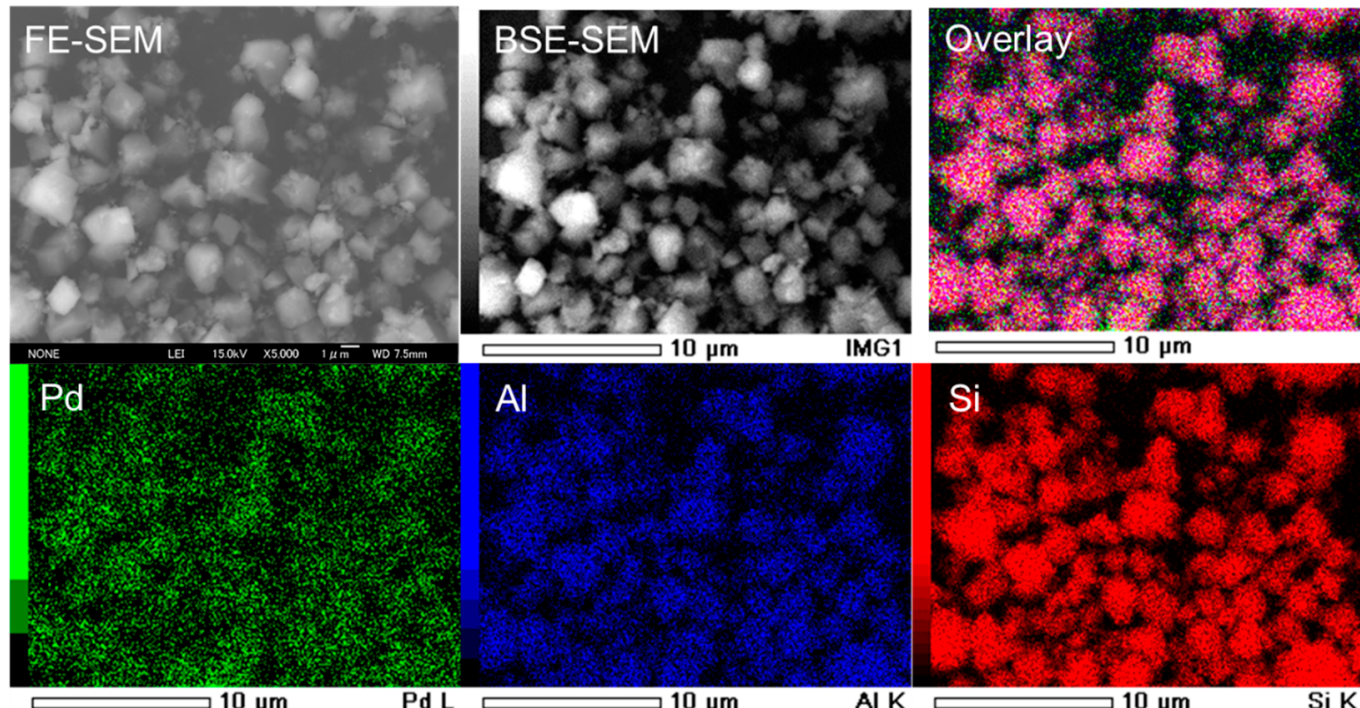

Al

Si

Figure 5. SEM images and elemental mapping of (a) Pd+CHA obtained by physical mixing of commercially available Pd black and CHA zeolites, and (b) $\mathrm{Pd}+\mathrm{CHA}(\mathrm{NO})$ obtained by $\mathrm{H}_{2}$ pretreatment and $\mathrm{NO}$ treatment of $\mathrm{Pd}+\mathrm{CHA}$.
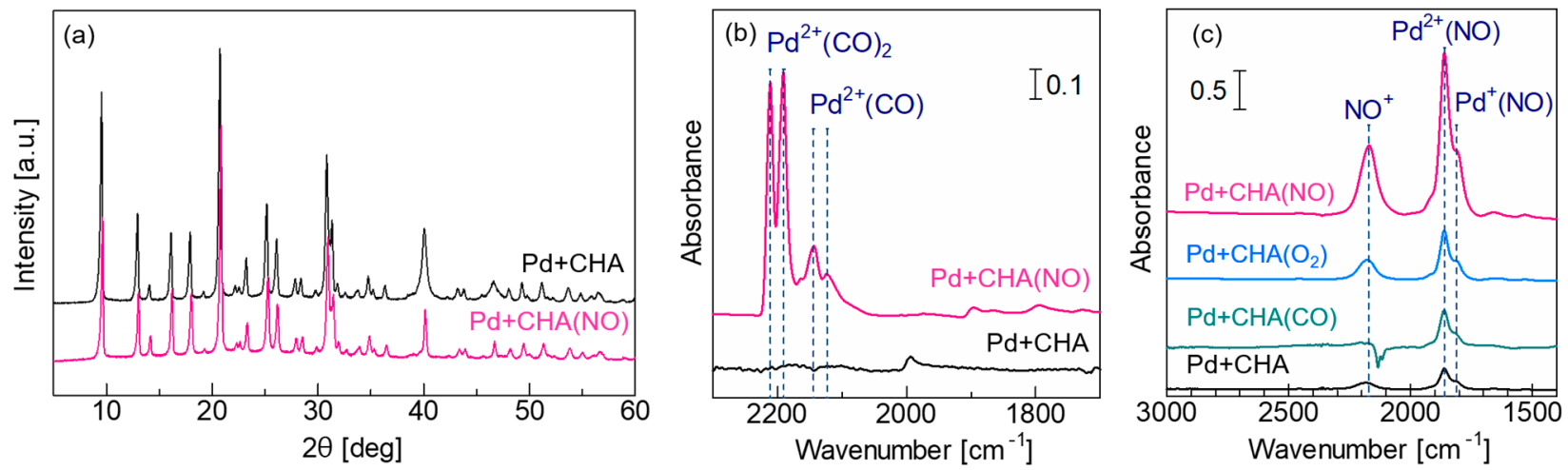

Figure 6. (a) XRD patterns and FTIR spectroscopy of (b) CO adsorption at room temperature and (c) NO adsorption at $100{ }^{\circ} \mathrm{C}$ for a series of Pd $+\mathrm{CHA}$. Detailed procedures are described in the SI.

several zeolites, such as FER, MFI, MOR, BEA, and Y, with $\mathrm{NO}$ and then $\mathrm{NO} / \mathrm{Pd}$ values were compared by $\mathrm{NO}$ adsorption experiment (Table 2). Note that $\mathrm{Al}$ contents in zeolites $(0.9-3.2 \mathrm{mmol} / \mathrm{g})$ are much higher than that required 
Table 1. Comparison of NO/Pd Values Determined by NO Adsorption Experiments at $100{ }^{\circ} \mathrm{C}$ for a Series of PdModified CHA or $\mathrm{SiO}_{2}$ under Different Treatments ${ }^{a}$

\begin{tabular}{|c|c|c|c|}
\hline Sample & Treatment & $\begin{array}{c}\mathrm{NO} / \mathrm{Pd} \\
{[\%]}\end{array}$ & $\begin{array}{l}\mathrm{Pd} \text { cation }^{d} \\
{[\mathrm{wt} \%]}\end{array}$ \\
\hline \multirow[t]{3}{*}{$\mathrm{Pd}_{\mathrm{imp}} / \mathrm{CHA}^{b}$} & None & 32.6 & 1.76 \\
\hline & $\begin{array}{l}\mathrm{H}_{2} \text { followed by } \mathrm{NO} \\
\quad(30 \mathrm{~min})\end{array}$ & 76.1 & 4.11 \\
\hline & $\mathrm{NO}(30 \mathrm{~min})$ & 49.1 & 2.65 \\
\hline \multirow[t]{4}{*}{$\mathrm{Pd}+\mathrm{CHA}^{b}$} & None & 9.9 & 0.53 \\
\hline & NO $(2 \mathrm{~h})$ & 76.3 & 4.12 \\
\hline & $\mathrm{O}_{2}(2 \mathrm{~h})$ & 21.4 & 1.16 \\
\hline & $\mathrm{CO}(2 \mathrm{~h})$ & 15.4 & 0.83 \\
\hline \multirow[t]{2}{*}{$\mathrm{Pd}_{\mathrm{imp}} / \mathrm{SiO}_{2}{ }^{c}$} & None & 1.7 & 0.09 \\
\hline & $\begin{array}{l}\mathrm{H}_{2} \text { followed by NO } \\
(30 \mathrm{~min})\end{array}$ & 1.5 & 0.08 \\
\hline
\end{tabular}

${ }^{a}$ The details of $\mathrm{NO}$ adsorption experiments and adsorption coefficient are described in the SI. ${ }^{b}$ Total Pd loading amount: $5.4 \mathrm{wt} \% .{ }^{{ }^{c}}$ Total Pd loading amount: $5.0 \mathrm{wt} \% .{ }^{d}$ Estimated from the total Pd loading amount and $\mathrm{NO} / \mathrm{Pd}$ value.

Table 2. NO/Pd Values Determined by NO Adsorption Experiments at $100{ }^{\circ} \mathrm{C}$ for the Reaction of Physical Mixture of Pd Black and Other Zeolites with Different Framework Types under $\mathrm{NO}$ at $600{ }^{\circ} \mathrm{C}^{a}$

\begin{tabular}{ccccc} 
Zeolites & SAR $^{b}$ & $\begin{array}{c}\text { Total Pd loading } \\
\text { [wt \%] }\end{array}$ & $\begin{array}{c}\text { NO/Pd } \\
{[\%]}\end{array}$ & $\begin{array}{c}\text { Pd cation } \\
\text { [wt } \%\end{array}$ \\
\hline CHA & 13.7 & 5.4 & 76.3 & 4.12 \\
CHA & 13.7 & 3.0 & 89.5 & 2.69 \\
CHA & 13.7 & 1.0 & 91.2 & 0.86 \\
FER & 18.0 & 1.0 & 93.4 & 0.93 \\
MFI & 22.3 & 1.0 & 93.7 & 0.94 \\
MOR & 20.0 & 1.0 & 73.0 & 0.73 \\
BEA & 17.5 & 1.0 & 48.9 & 0.49 \\
Y & 5.5 & 1.0 & 5.1 & 0.05
\end{tabular}

${ }^{a}$ The details of $\mathrm{NO}$ adsorption experiments and adsorption coefficient are described in the $\mathrm{SI} .{ }^{b} \mathrm{SiO}_{2} / \mathrm{Al}_{2} \mathrm{O}_{3}$ ratio. ${ }^{c}$ Estimated from the total $\mathrm{Pd}$ loading amount and $\mathrm{NO} / \mathrm{Pd}$ value.

to stabilize $1 \mathrm{wt} \%$ of $\mathrm{Pd}^{2+}$ cations (ca. $0.19 \mathrm{mmol} / \mathrm{g}$ ) in all cases (The details are described in the SI). For FER, MFI, and MOR zeolites, high NO/Pd values were achieved (73.0$93.7 \%$ ), while a moderate $\mathrm{NO} / \mathrm{Pd}$ value was obtained in the case of BEA $(48.9 \%)$. The use of $\mathrm{Y}$ zeolites resulted in an extremely low NO/Pd value (5.1\%). These results showed that the present method utilizing atomic dispersion of bulk Pd was applicable to other zeolites tested (CHA, FER, MFI, MOR, and BEA) except for $\mathrm{Y}$ zeolites. In all the case, the XRD patterns obtained after the NO treatment showed that the diffraction peak derived from $\mathrm{Pd}(111)$ decreased in intensity (Figure S4), indicating that the reaction of bulk Pd with NO occurred for all the zeolites. Taking into account the report on redispersion of small Pd NPs by $\mathrm{NO}$ in $\mathrm{Y}$ zeolites at room temperature, $^{21} \mathrm{Y}$ zeolites are unlikely to stabilize atomic $\mathrm{Pd}$ cations in high reaction temperature.

3.4. Spectroscopic and Theoretical Elucidation of Plausible Reaction in Atomic Dispersion of Bulk Pd into CHA Zeolites

All described results for $\mathrm{Pd}_{\text {imp }} / \mathrm{CHA}, \mathrm{Pd}+\mathrm{CHA}$, and $\mathrm{Pd}_{\text {imp }} /$ $\mathrm{SiO}_{2}$ and those after different treatments (Table 1) clearly showed that (1) the reaction of $\operatorname{Pd}(0)$ metal with $\mathrm{NO}$ is a key and (2) $\mathrm{Pd}^{2+}$ cations are formed on zeolite $\mathrm{Al}$ sites. To elucidate the structural evolution of Pd species during atomic dispersion, an in situ XAS measurement was carried out for Pd $+\mathrm{CHA}$ during $\mathrm{NO}$ treatment $\left(4 \% \mathrm{NO} / \mathrm{He}\right.$ flow, $600{ }^{\circ} \mathrm{C}$ ). Normalized XANES spectra obtained at $t=0,2,20,60,120$, and $145 \mathrm{~min}$ are shown in Figure $7 \mathrm{a}$. Prior to measurement $\mathrm{Pd}$
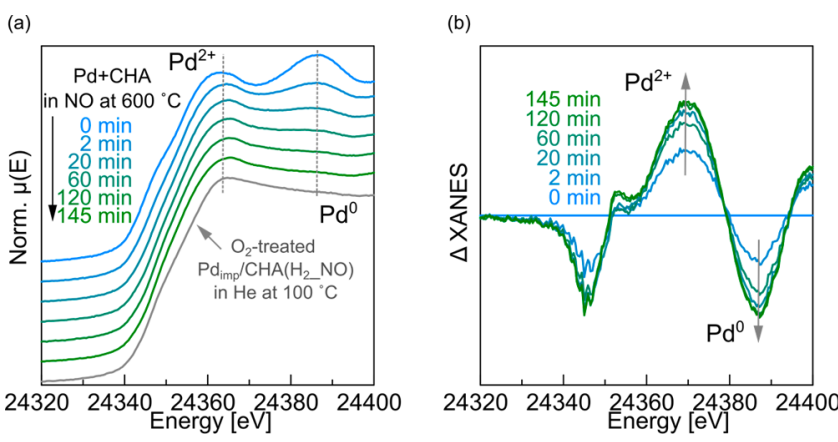

Figure 7. (a) In situ XANES spectra during the reaction of $\mathrm{Pd}+\mathrm{CHA}$ under $4 \% \mathrm{NO} / \mathrm{He}$ flow at $600{ }^{\circ} \mathrm{C}$ and $\mathrm{O}_{2}$-treated $\mathrm{Pd}_{\text {imp }} / \mathrm{CHA}$ $\left(\mathrm{H}_{2} \mathrm{NO}\right)$ under $\mathrm{He}$ flow at $100{ }^{\circ} \mathrm{C}$. (b) Corresponding $\triangle$ XANES spectra. The data were obtained by subtraction with the spectrum taken at $0 \mathrm{~min}$.

+ $\mathrm{CHA}$ was treated with $0.5 \% \mathrm{H}_{2} / \mathrm{He}$, followed by purging under $\mathrm{He}$ flow. The spectrum after pretreatment showed a peak unique to $\mathrm{Pd}(0)$ metal around $24388 \mathrm{eV}$ with an absorption edge $\left(E_{0}\right)$ at $24344.7 \mathrm{eV}$. When $\mathrm{NO} / \mathrm{He}$ was introduced, the peak around $24388 \mathrm{eV}$ decreased, with the concomitant appearance of a new peak derived from $\mathrm{Pd}^{2+}$ species around $24365 \mathrm{eV}$, while the absorption edge shifted toward higher energy. After 120 min of treatment with NO, the peak around $24388 \mathrm{eV}$ disappeared, and the absorption edge remained unchanged $\left(E_{0}=24349.0 \mathrm{eV}\right)$. The XANES spectrum at $120 \mathrm{~min}$ resembled $\mathrm{O}_{2}$-treated $\mathrm{Pd}_{\text {imp }} / \mathrm{CHA}$ $\left(\mathrm{H}_{2} \_\mathrm{NO}\right)$ under $\mathrm{He}$ flow at $100{ }^{\circ} \mathrm{C}$, implying the formation of $\mathrm{Pd}^{2+}$ cations primarily. These changes are shown more clearly in the $\triangle$ XANES spectra (Figure $7 \mathrm{~b}$ ). The peak derived from $\operatorname{Pd}(0)$ species steeply decreased in intensity with the appearance of the peak assignable to $\mathrm{Pd}^{2+}$ species in the initial stage $(t=0-20 \mathrm{~min})$ and, then, continuously decreased until $t$ $=120 \mathrm{~min}$. From these results, Pd black was atomically dispersed by oxidation of $\mathrm{Pd}(0)$ species toward $\mathrm{Pd}^{2+}$.

In situ DRIFTS measurements were also conducted by monitoring the produced gas. The background spectrum was taken after pretreatment of $\mathrm{Pd}+\mathrm{CHA}$ with $\mathrm{H}_{2} / \mathrm{He}$, followed by a He purge. After that, the gas was changed to $4 \% \mathrm{NO} / \mathrm{He}$, while recording the spectra continuously. A negative band was observed around $3600 \mathrm{~cm}^{-1}$ upon exposure to $\mathrm{NO}$, and its absorbance became more negative with extended treatment times (Figure 8a). This phenomenon can be ascribed to consumption of protons on $\mathrm{Al}$ sites $\left(\mathrm{H}^{+} \mathrm{O}_{z}^{-}\right)$of $\mathrm{CHA}$ zeolites, owing to a cation-exchange reaction with $\mathrm{Pd}^{2+}$ cations. Further, $\mathrm{NO}$ adsorbed on in situ generated $\mathrm{Pd}^{2+}$ cations was detected. The gas product analysis revealed that $\mathrm{N}_{2} \mathrm{O}$ was generated as a main gas product (Figure $8 \mathrm{~b}$ ). Plots of $\mathrm{N}_{2} \mathrm{O}$ concentration and IR area for $\mathrm{H}^{+} \mathrm{O}_{z}^{-}$versus time (Figure 8c) showed that $\mathrm{N}_{2} \mathrm{O}$ formation and consumption of $\mathrm{H}^{+} \mathrm{O}_{z}^{-}$occurred simultaneously. Combined with in situ XAS results, the atomic dispersion of bulk $\mathrm{Pd}$ can be described by the following equation (eq 1 ).

$$
\mathrm{Pd}(0)+2 \mathrm{NO}+2\left(\mathrm{H}^{+} \mathrm{O}_{z}^{-}\right) \rightarrow 2 \mathrm{O}_{z}^{-} \mathrm{Pd}^{2+}+\mathrm{N}_{2} \mathrm{O}+\mathrm{H}_{2} \mathrm{O}
$$



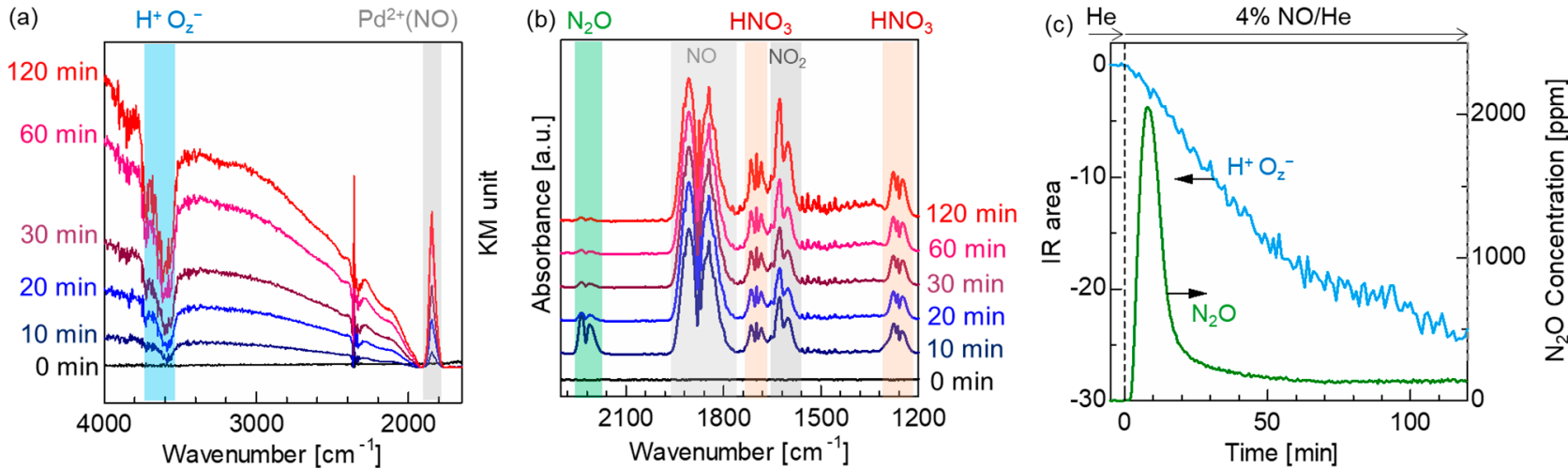

Figure 8. (a) In situ DRIFTS spectra during the reaction of Pd+CHA under $4 \% \mathrm{NO} / \mathrm{He}$ flow at $600{ }^{\circ} \mathrm{C}$. (b) Spectra for $\mathrm{NO}_{x}$ gases monitored by IR with a gas cell. (c) Plots of $\mathrm{N}_{2} \mathrm{O}$ concentration and IR area for $\mathrm{H}^{+} \mathrm{O}_{z}^{-}$.
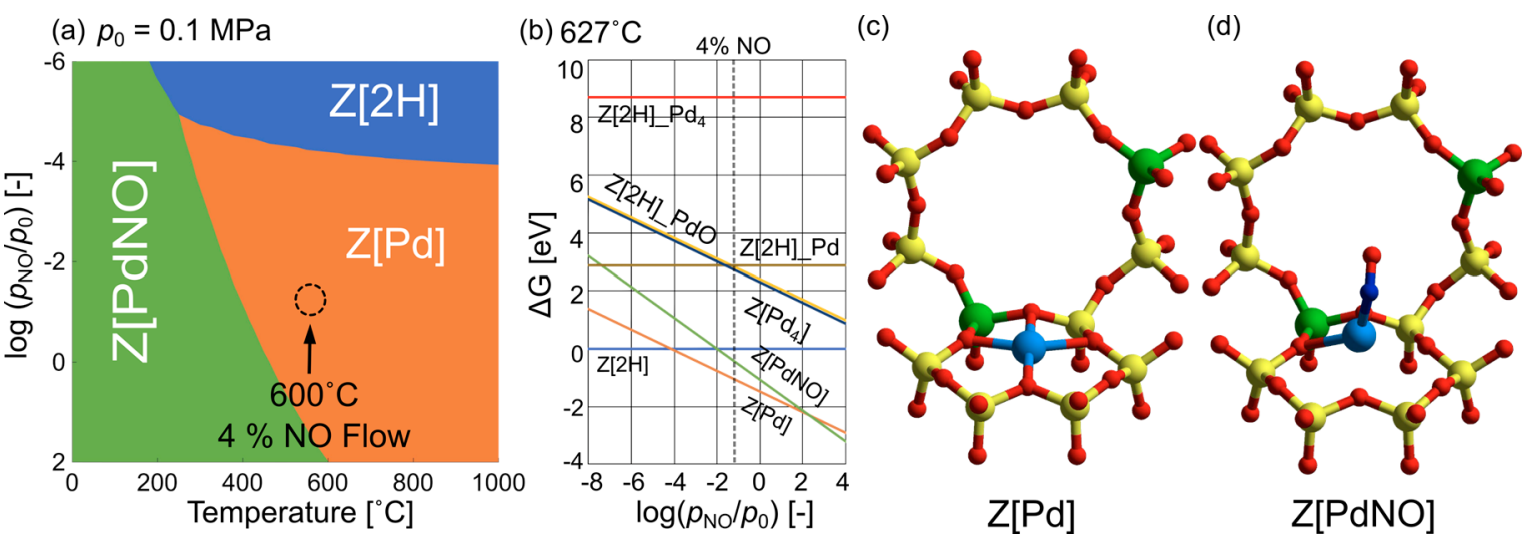

Figure 9. (a) Relative Gibbs free energy $(\Delta G)$ of the Pd species on paired $\mathrm{Al}$ sites (denoted as $\mathrm{Z}$ ) in CHA zeolite, and a phase diagram showing the lowest-energy species as a function of $\mathrm{NO}$ partial pressure $\left(\log \left(p_{\mathrm{NO}} / p_{0}\right)\right)$ and temperature. (b) $\Delta G$ of $\mathrm{Pd}$ species on $\mathrm{Z}$ in $\mathrm{CHA}$ zeolite as a function of $\log \left(p_{\mathrm{NO}} / p_{0}\right)$ at $627^{\circ} \mathrm{C}$. The optimized structures of (c) Z[Pd] and (d) Z[PdNO] are given. Yellow: Si, Red: O, Green: Al, Blue: N, Cyan: Pd. Only atoms around $\mathrm{Z}$ are shown for clarity.

A similar equation was proposed by Perimet and coworkers. ${ }^{21}$ The amount of generated $\mathrm{N}_{2} \mathrm{O}$ was estimated to be $328 \mu \mathrm{mol} / \mathrm{g}$, which was ca. $65 \%$ of the total molar amount of $\mathrm{Pd}(508 \mu \mathrm{mol} / \mathrm{g})$, supporting that the above equation (eq 1$)$ is the most plausible reaction of atomic dispersion. However, $\mathrm{HNO}_{3}$ was detected instead of $\mathrm{H}_{2} \mathrm{O}$. The generated $\mathrm{H}_{2} \mathrm{O}$ may react with $\mathrm{NO}_{2}$ derived from a decomposition reaction of $\mathrm{NO}$ under high temperature, ${ }^{58}$ yielding $\mathrm{HNO}_{3}$. Furthermore, atomic dispersion of bulk Pd in CHA zeolites was theoretically studied. Periodic DFT calculations, combined with ab initio thermodynamics analysis, were used to figure a phase diagram to predict plausible $\mathrm{Pd}$ species at relevant partial pressures and temperatures. ${ }^{59,60}$ The following equilibrium reaction was considered (eq 2):

$$
\begin{aligned}
& \mathrm{Z}[2 \mathrm{H}]+n \mathrm{Pd}_{\text {bulk }}+(-x-y+2 z+2) \mathrm{NO} \\
& \leftrightharpoons \mathrm{Z}\left[\mathrm{H}_{x(0 \text { or } 2)} \mathrm{Pd}_{n} \mathrm{~N}_{y} \mathrm{O}_{z}\right]+\left(-\frac{1}{2} x+1\right) \mathrm{H}_{2} \mathrm{O} \\
& +\left(-\frac{1}{2} x-y+z+1\right) \mathrm{N}_{2} \mathrm{O}
\end{aligned}
$$

Paired $\mathrm{Al}$ sites possessing two $\mathrm{O}_{z}^{-}$are denoted as $\mathrm{Z}$. Detailed definitions for relative Gibbs free energies $(\Delta G)$ of $\mathrm{Z}\left[\mathrm{H}_{x(\text { oor } 2)} \mathrm{Pd}_{n} \mathrm{~N}_{y} \mathrm{O}_{z}\right]$ and chemical potentials of gaseous molecules are described in the SI. The third-nearest-neighbor site in the eight-membered-ring is considered as $\mathrm{Z}$, where the $\mathrm{Al}-\mathrm{Al}$ distance is moderate $(7.18 \AA)$ among paired $\mathrm{Al}$ sites in
CHA zeolite. ${ }^{61}$ Proton-type CHA zeolite, in which two protons are possessed at $\mathrm{Z}$ for charge compensation, is treated as the reference model. This model is denoted as $\mathrm{Z}[2 \mathrm{H}]$, meaning that $\mathrm{Pd}$ species remain as bulk $\mathrm{Pd}$. For divalent cationic species, a $\mathrm{Pd}^{2+}$ cation $(\mathrm{Z}[\mathrm{Pd}])$, NO-adsorbed $\mathrm{Pd}^{2+}$ cation $(\mathrm{Z}[\mathrm{PdNO}])$, and cationic Pd tetramer $\left(\mathrm{Z}\left[\mathrm{Pd}_{4}\right]\right)$ are taken into account. A PdO monomer ( $\mathrm{Z}[2 \mathrm{H}]$ PdO), Pd atom $(\mathrm{Z}[2 \mathrm{H}]$ $\mathrm{Pd})$, and $\mathrm{Pd}$ tetramer $\left(\mathrm{Z}[2 \mathrm{H}]-\mathrm{Pd}_{4}\right)$ are evaluated as uncoordinated neutral species. Note that $\mathrm{Z}\left[\mathrm{Pd}_{4}\right]$ and $\mathrm{Z}[2 \mathrm{H}]$ $\mathrm{Pd}_{4}$ have been applied as representative models of small $\mathrm{Pd}$ clusters in previous papers. ${ }^{62,63}$ The structural information (CONTCAR files) of all the considered structures can be found in the SI. Note that the simulated XANES spectrum for the optimized $\mathrm{Z}[\mathrm{Pd}]$ structure is similar to the experimental one for $\mathrm{Pd}_{\text {imp }} / \mathrm{CHA}\left(\mathrm{H}_{2} \mathrm{NO}\right.$ ) (Figure S5), confirming that our model is reasonable as $\overline{\mathrm{P}} \mathrm{d}^{2+}$ cations in CHA zeolites.

Figure 9a shows the phase diagram as a function of partial pressure of $\mathrm{NO}\left(\log \left(p_{\mathrm{NO}} / p_{0}\right)\right)$ and temperature. $\mathrm{Z}[\mathrm{PdNO}]$ (Figure 9c) is the lowest species in free energy over a wide range of lower temperature conditions $\left(<300{ }^{\circ} \mathrm{C}\right)$. With an increase of temperature at $\log \left(p_{\mathrm{NO}} / p_{0}\right)>-4, \mathrm{Z}[\mathrm{Pd}]$ (Figure $9 \mathrm{~d}$ ) becomes the most stable $\mathrm{Pd}$ species, while $\mathrm{Z}[2 \mathrm{H}]$ is predicted as the most stable structure under low $\mathrm{NO}$ concentrations in the high-temperature region. Figure $9 \mathrm{~b}$ shows the calculated $\Delta G$ as a function of $\log \left(p_{\mathrm{NO}} / p_{0}\right)$ at 627 ${ }^{\circ} \mathrm{C}$. In the lower concentration region, $\Delta G$ values, for all considered $\mathrm{Pd}$ species, are higher than for $\mathrm{Z}[2 \mathrm{H}]$. With 
increasing NO concentration, $\Delta G$ for $\mathrm{Z}[\mathrm{PdNO}], \mathrm{Z}[\mathrm{Pd}]$, $\mathrm{Z}[2 \mathrm{H}] \_\mathrm{PdO}$, and $\mathrm{Z}\left[\mathrm{Pd}_{4}\right]$ decrease. At $\log \left(p_{\mathrm{NO}} / p_{0}\right)=-1.4$, corresponding to experimental conditions employed in this study $(4 \% \mathrm{NO} / \mathrm{He}), \mathrm{Z}[\mathrm{PdNO}]$ and $\mathrm{Z}[\mathrm{Pd}]$ are thermodynamically more favorable than $\mathrm{Z}[2 \mathrm{H}]$.

To confirm the requirement of high temperature for atomic dispersion of bulk Pd, the physical mixture of Pd black (5.4 wt $\%)$ with $\mathrm{CHA}$ zeolites was treated by $\mathrm{NO}$ at different temperatures from $30-600{ }^{\circ} \mathrm{C}$. The results are summarized in Figure S6 and Table S3 in the SI. The atomic dispersion scarcely occurred at room temperature even by extending the time to $48 \mathrm{~h}(\mathrm{NO} / \mathrm{Pd}<1 \%)$, and $600{ }^{\circ} \mathrm{C}$ was required to obtain high $\mathrm{NO} / \mathrm{Pd}$ values $(76.3 \%)$. Furthermore, the reason for the necessity of high temperature was theoretically studied. Several previous studies on atomic dispersion of Pd NPs under oxidative conditions proposed that the formation of mononuclear $\mathrm{Pd}$ species, including $\mathrm{PdO},{ }^{21} \mathrm{Pd}(\mathrm{OH})_{2},{ }^{35}$ and $\mathrm{Pd}$ nitrosyl complexes, ${ }^{64}$ play key roles for the dispersion. In our experiments for the atomic dispersion of Pd black into $\mathrm{CHA}$ zeolites, the use of $\mathrm{O}_{2}$ instead of $\mathrm{NO}$ induced the formation of bulk $\mathrm{PdO}$, as indicated by XRD (Figure S7), and resulted in the significant decrease of $\mathrm{Pd}^{2+}$ cations (Table 1) while any mobile Pd-nitrosyl complex was not detected during the dispersion process using NO unfortunately (confirmed by FTIR). Therefore, the formation of mononuclear PdO from partially oxidized Pd surfaces was considered as a simple calculation model to discuss the difference between bulk Pd and Pd NPs in NO-induced atomic dispersion. A Pd(111) surface slab and $\mathrm{Pd}_{38}$ cluster ${ }^{65}$ with surface atomic $\mathrm{O}$ species were applied as representative models for Pd bulk surface and $\mathrm{Pd}$ NPs, respectively, and the formation energy of PdO vacancy $\left(E_{\text {PdOvac }}\right)$ was compared (the used models and detailed definition can be found in the SI). The $E_{\text {PdOvac }}$ for the $\operatorname{Pd}(111)$ surface is highly endothermic $(168.7 \mathrm{~kJ} / \mathrm{mol})$ while that for the $\mathrm{Pd}_{38}$ cluster is relatively small $(4.3 \mathrm{~kJ} / \mathrm{mol}$ ) (Figure $\mathrm{S} 8 \mathrm{a}$ ). Furthermore, the diffusion of generated $\mathrm{PdO}$ species in $\mathrm{CHA}$ zeolite pores was also investigated by transition state calculation, resulting in the small diffusion barrier through the eight-membered ring $(28.3 \mathrm{~kJ} / \mathrm{mol}$, Figure $\mathrm{S} 8 \mathrm{~b}){ }^{66}$ Considering the previous studies on reaction of metallic $\mathrm{Pd}$ with $\mathrm{NO},{ }^{6,68}$ a plausible mechanism can be proposed as follows. A surface Pd atom is oxidized by the atomic O species generated by the dissociation of a $\mathrm{NO}$ molecule on a Pd metal surface. ${ }^{67} \mathrm{~A} \mathrm{~N}_{2} \mathrm{O}$ molecule is concomitantly generated from the remaining $\mathrm{N}$ and another NO. ${ }^{68}$ Subsequently, a mononuclear $\mathrm{PdO}$ is formed from the oxidized $\mathrm{Pd}$ surface. This step is highly endothermic and thus requires high temperature. The generated $\mathrm{PdO}$ species can easily diffuse and access paired $\mathrm{Al}$ sites in $\mathrm{CHA}$ zeolites, and finally isolated $\mathrm{Pd}^{2+}$ cations are placed at ion-exchange sites with concomitant formation of $\mathrm{H}_{2} \mathrm{O}$. The paired $\mathrm{Al}$ sites in $\mathrm{CHA}$ zeolites can serve as anchoring sites of $\mathrm{Pd}^{2+}$ cations even under high reaction temperature, enabling NO-facilitated atomic dispersion of bulk Pd.

\section{CONCLUSIONS}

We have shown that bulk Pd can be atomically dispersed into small pores of $\mathrm{CHA}$ zeolite with $4 \% \mathrm{NO}$ flow at $600{ }^{\circ} \mathrm{C}$. The microscopic (SEM, STEM, EDX) and spectroscopic (XRD, FTIR, XAS) characterizations showed that $\mathrm{Pd}^{2+}$ cations on zeolite anionic sites were mainly formed. The amount of $\mathrm{Pd}^{2+}$ cations reached $4.1 \mathrm{wt} \%$, which is higher than the highest value reported previously. The solid-state synthesis of $\mathrm{Pd}$ - exchanged CHA from commercially available Pd black and CHA zeolites was also demonstrated, where NO was the most effective among other reactive gases tested, such as $\mathrm{O}_{2}$ and CO. The present method utilizing atomic dispersion of $\mathrm{Pd}$ black was applicable to other zeolites with different framework types. From in situ XAS and DRIFTS, combined with online gas monitoring, atomic dispersion occurs through oxidation of $\mathrm{Pd}$ metal by $\mathrm{NO}$, yielding $\mathrm{Pd}$ cations on $\mathrm{Al}$ sites with concomitant formation of $\mathrm{N}_{2} \mathrm{O}$ and $\mathrm{H}_{2} \mathrm{O}$ (as $\mathrm{HNO}_{3}$ ). The phase diagram, determined by $a b$ initio thermodynamics analysis, showed that divalent $\mathrm{Pd}$ cations on paired $\mathrm{Al}$ sites are thermodynamically favored under the experimental conditions ( $4 \% \mathrm{NO}$ and $600{ }^{\circ} \mathrm{C}$ ), consistent with the occurrence of atomic dispersion of bulk Pd. The DFT calculations suggest that the generation of mononuclear $\mathrm{Pd}$ species from bulk Pd is a highly endothermic reaction and thus requires high reaction temperature. The generated mononuclear Pd species can easily diffuse into small-pore CHA zeolites to afford $\mathrm{Pd}^{2+}$ cations on paired $\mathrm{Al}$ sites. The paired $\mathrm{Al}$ sites in CHA zeolites stabilize atomic Pd cations even under severe reaction conditions, allowing the preparation of $\mathrm{Pd}^{2+}$ loaded CHA zeolites from commercially available Pd black and CHA zeolites. This work demonstrates the potential of atomic dispersion for preparation of metal cation-exchanged smallpore zeolites that cannot be obtained by conventional aqueousphase cation-exchange methods. It is noteworthy that the present method can be combined with the conventional methods. The NO adsorption/desorption properties and hydrothermal stability of Pd-loaded CHA zeolites with high loading of $\mathrm{Pd}^{2+}$ cations are now under investigation for PNA applications.

\section{ASSOCIATED CONTENT}

\section{Supporting Information}

The Supporting Information is available free of charge at https://pubs.acs.org/doi/10.1021/jacsau.0c00112.

Detailed procedures and results of experiments and calculations (PDF)

Complete structure files for the calculated structures (ZIP)

\section{AUTHOR INFORMATION}

\section{Corresponding Authors}

Zen Maeno - Institute for Catalysis, Hokkaido University, Sapporo 001-0021, Japan; ○ orcid.org/0000-0002-9300219X; Email: maeno@cat.hokudai.ac.jp

Ken-ichi Shimizu - Institute for Catalysis, Hokkaido University, Sapporo 001-0021, Japan; Elements Strategy Initiative for Catalysts and Batteries, Kyoto University, Katsura, Kyoto 615-8520, Japan; ㅇoㅇd.org/0000-00030501-0294; Email: kshimizu@cat.hokudai.ac.jp

\section{Authors}

Shunsaku Yasumura - Institute for Catalysis, Hokkaido University, Sapporo 001-0021, Japan

Hajime Ide - Institute for Catalysis, Hokkaido University, Sapporo 001-0021, Japan

Taihei Ueda - Institute for Catalysis, Hokkaido University, Sapporo 001-0021, Japan

Yuan Jing - Institute for Catalysis, Hokkaido University, Sapporo 001-0021, Japan 
Chong Liu - Institute for Catalysis, Hokkaido University, Sapporo 001-0021, Japan; 이이이.org/0000-0003-03118744

Kenichi Kon - Institute for Catalysis, Hokkaido University, Sapporo 001-0021, Japan

Takashi Toyao - Institute for Catalysis, Hokkaido University, Sapporo 001-0021, Japan; Elements Strategy Initiative for Catalysts and Batteries, Kyoto University, Katsura, Kyoto 615-8520, Japan; 이이이.org/0000-0002-6062-5622

Complete contact information is available at: https://pubs.acs.org/10.1021/jacsau.0c00112

\section{Author Contributions}

S.Y. performed the atomic dispersion experiments, in situ DRIFTS measurements, and DFT calculations and wrote the draft. H.I. examined the $\mathrm{NO} / \mathrm{CO}$ adsorption experiments as well as XRD and SEM measurements. T.U. conducted the $\mathrm{NH}_{3}$ adsorption experiments and $a b$ initio thermodynamics analysis. J.Y. performed in situ XAS measurements and analyzed the data. K.K. performed SEM, STEM, and EDX observations. C.L., T.T., and Z.M. critically revised the manuscript. K.S. designed and supervised the whole project.

Notes

The authors declare no competing financial interest.

\section{ACKNOWLEDGMENTS}

This study was financially supported by KAKENHI (Grant Nos. No. 17H01341, 20H02518, and 20H02775) from the Japan Society for the Promotion of Science (JSPS) and by the Japanese Ministry of Education, Culture, Sports, Science, and Technology (MEXT) within the projects "Integrated Research Consortium on Chemical Sciences (IRCCS)" and "Elements Strategy Initiative to Form Core Research Center" (JPMXP0112101003). This study was also supported by the JST-CREST projects JPMJCR17J3 and JPMJCR15P4. C.L. acknowledges a JSPS postdoctoral fellowship (No. P19059). The authors sincerely thank the technical division of the Institute for Catalysis (Hokkaido University) for manufacturing experimental equipment as well as the technical staff at the Open Facility of Hokkaido University for their assistance with STEM observations. X-ray absorption measurements were performed at the BL14B2 facilities of SPring- 8 at the Japan Synchrotron Radiation Research Institute (JASRI) (No. 2019B1686). Part of the calculations were conducted on supercomputers at RIIT (Kyushu Univ.).

\section{REFERENCES}

(1) Liu, L.; Corma, A. Metal Catalysts for Heterogeneous Catalysis: From Single Atoms to Nanoclusters and Nanoparticles. Chem. Rev. 2018, 118, 4981-5079.

(2) Mee, S. J. Supported Metals in Catalysis Edited by James A. Anderson and Marcos Fernandez Garcia. Chem. Ind. (Chichester, United Kingdom) 2013, 77, 47.

(3) Choi, S.; Drese, J. H.; Jones, C. W. Adsorbent Materials for Carbon Dioxide Capture from Large Anthropogenic Point Sources. ChemSusChem 2009, 2, 796-854.

(4) Wang, S.; Peng, Y. Natural Zeolites as Effective Adsorbents in Water and Wastewater Treatment. Chem. Eng. J. 2010, 156, 11-24.

(5) Liu, L.; Corma, A. Evolution of Isolated Atoms and Clusters in Catalysis. Trends Chem. 2020, 2, 383-400.

(6) Goodman, E. D.; Schwalbe, J. A.; Cargnello, M. Mechanistic Understanding and the Rational Design of Sinter-Resistant Heterogeneous Catalysts. ACS Catal. 2017, 7, 7156-7173.
(7) Simonsen, S. B.; Chorkendorff, I.; Dahl, S.; Skoglundh, M.; Sehested, J.; Helveg, S. Ostwald Ripening in a $\mathrm{Pt} / \mathrm{SiO}_{2}$ Model Catalyst Studied by In Situ TEM. J. Catal. 2011, 281, 147-155.

(8) Matos, J.; Ono, L. K.; Behafarid, F.; Croy, J. R.; Mostafa, S.; Delariva, A. T.; Datye, A. K.; Frenkel, A. I.; Roldan Cuenya, B. In Situ Coarsening Study of Inverse Micelle-Prepared Pt Nanoparticles Supported on $\gamma-\mathrm{Al}_{2} \mathrm{O}_{3}$ : Pretreatment and Environmental Effects. Phys. Chem. Chem. Phys. 2012, 14, 11457-11467.

(9) DeRita, L.; Resasco, J.; Dai, S.; Boubnov, A.; Thang, H. V.; Hoffman, A. S.; Ro, I.; Graham, G. W.; Bare, S. R.; Pacchioni, G.; Pan, X.; Christopher, P. Structural Evolution of Atomically Dispersed Pt Catalysts Dictates Reactivity. Nat. Mater. 2019, 18, 746-751.

(10) Gänzler, A. M.; Casapu, M.; Vernoux, P.; Loridant, S.; Cadete Santos Aires, F. J.; Epicier, T.; Betz, B.; Hoyer, R.; Grunwaldt, J.-D. Tuning the Structure of Platinum Particles on Ceria In Situ for Enhancing the Catalytic Performance of Exhaust Gas Catalysts. Angew. Chem., Int. Ed. 2017, 56, 13078-13082.

(11) Hill, A. J.; Seo, C. Y.; Chen, X.; Bhat, A.; Fisher, G. B.; Lenert, A.; Schwank, J. W. Thermally Induced Restructuring of $\mathrm{Pd} @ \mathrm{CeO}_{2}$ and Pd@SiO ${ }_{2}$ Nanoparticles as a Strategy for Enhancing LowTemperature Catalytic Activity. ACS Catal. 2020, 10, 1731-1741.

(12) Lee, H.; Habas, S. E.; Kweskin, S.; Butcher, D.; Somorjai, G. A.; Yang, P. Morphological Control of Catalytically Active Platinum Nanocrystals. Angew. Chem., Int. Ed. 2006, 45, 7824-7828.

(13) Hansen, T. W.; DeLaRiva, A. T.; Challa, S. R.; Datye, A. K. Sintering of Catalytic Nanoparticles: Particle Migration or Ostwald Ripening? Acc. Chem. Res. 2013, 46, 1720-1730.

(14) Aitbekova, A.; Wu, L.; Wrasman, C. J.; Boubnov, A.; Hoffman, A. S.; Goodman, E. D.; Bare, S. R.; Cargnello, M. Low-Temperature Restructuring of $\mathrm{CeO}_{2}$-Supported $\mathrm{Ru}$ Nanoparticles Determines Selectivity in $\mathrm{CO}_{2}$ Catalytic Reduction. J. Am. Chem. Soc. 2018, 140, 13736-13745.

(15) Ferré, G.; Aouine, M.; Bosselet, F.; Burel, L.; Cadete Santos Aires, F. J.; Geantet, C.; Ntais, S.; Maurer, F.; Casapu, M.; Grunwaldt, J. D.; Epicier, T.; Loridant, S.; Vernoux, P. Exploiting the Dynamic Properties of Pt on Ceria for Low-Temperature CO Oxidation. Catal. Sci. Technol. 2020, 10, 3904-3917.

(16) Nagai, Y.; Dohmae, K.; Ikeda, Y.; Takagi, N.; Tanabe, T.; Hara, N.; Guilera, G.; Pascarelli, S.; Newton, M. A.; Kuno, O.; Jiang, H.; Shinjoh, H.; Matsumoto, S. In Situ Redispersion of Platinum Autoexhaust Catalysts: An on-Line Approach to Increasing Catalyst Lifetimes? Angew. Chem., Int. Ed. 2008, 47, 9303-9306.

(17) Piccolo, L. Restructuring Effects of the Chemical Environment in Metal Nanocatalysis and Single-Atom Catalysis. Catal. Today 2020, in press. DOI: 10.1016/j.cattod.2020.03.052

(18) Delariva, A. T.; Hansen, T. W.; Challa, S. R.; Datye, A. K. In Situ Transmission Electron Microscopy of Catalyst Sintering. J. Catal. 2013, 308, 291-305.

(19) Newton, M. A.; Belver-Coldeira, C.; Martínez-Arias, A.; Fernández-García, M. Dynamic In Situ Observation of Rapid Size and Shape Change of Supported Pd Nanoparticles during CO/NO Cycling. Nat. Mater. 2007, 6, 528-532.

(20) Simonsen, S. B.; Chorkendorff, I.; Dahl, S.; Skoglundh, M.; Sehested, J.; Helveg, S. Direct Observations of Oxygen-Induced Platinum Nanoparticle Ripening Studied by In Situ TEM. J. Am. Chem. Soc. 2010, 132, 7968-7975.

(21) Che, M.; Dutel, J. F.; Gallezot, P.; Primet, M. A Study of the Chemisorption of Nitric Oxide on PdY Zeolite. Evidence for a Room Temperature Oxidative Dissolution of Pd Crystallites. J. Phys. Chem. 1976, 80, 2371-2381.

(22) Aylor, A. W.; Lobree, L. J.; Reimer, J. A.; Bell, A. T. Investigations of the Dispersion of Pd in H-ZSM-5. J. Catal. 1997, $172,453-462$.

(23) Feng, S.; Song, X.; Liu, Y.; Lin, X.; Yan, L.; Liu, S.; Dong, W.; Yang, X.; Jiang, Z.; Ding, Y. In Situ Formation of Mononuclear Complexes by Reaction-Induced Atomic Dispersion of Supported Noble Metal Nanoparticles. Nat. Commun. 2019, 10, 5281.

(24) Jones, J.; Xiong, H.; DeLaRiva, A. T.; Peterson, E. J.; Pham, H.; Challa, S. R.; Qi, G.; Oh, S.; Wiebenga, M. H.; Hernández, X. I. P.; 
Wamg, Y.; Datye, A. K. Thermally Stable Single-Atom Platinum-onCeria Catalysts via Atom Trapping. Science 2016, 353, 150-154.

(25) Moliner, M.; Gabay, J.; Kliewer, C.; Serna, P.; Corma, A. Trapping of Metal Atoms and Metal Clusters by Chabazite under Severe Redox Stress. ACS Catal. 2018, 8, 9520-9528.

(26) Maeno, Z.; Yasumura, S.; Wu, X.; Huang, M.; Liu, C.; Toyao, T.; Shimizu, K. Isolated Indium Hydrides in CHA Zeolites: Speciation and Catalysis for Nonoxidative Dehydrogenation of Ethane. J. Am. Chem. Soc. 2020, 142, 4820-4832.

(27) Sá, J.; Taylor, S. F. R.; Daly, H.; Goguet, A.; Tiruvalam, R.; He, Q.; Kiely, C. J.; Hutchings, G. J.; Hardacre, C. Redispersion of Gold Supported on Oxides. ACS Catal. 2012, 2, 552-560.

(28) Wei, S.; Li, A.; Liu, J. C.; Li, Z.; Chen, W.; Gong, Y.; Zhang, Q.; Cheong, W. C.; Wang, Y.; Zheng, L.; Xiao, H.; Chen, C.; Wamg, D.; Peng, Q.; Gu, L.; Han, X.; Li, J.; Li, Y. Direct Observation of Noble Metal Nanoparticles Transforming to Thermally Stable Single Atoms. Nat. Nanotechnol. 2018, 13, 856-861.

(29) Shwan, S.; Skoglundh, M.; Lundegaard, L. F.; Tiruvalam, R. R.; Janssens, T. V. W.; Carlsson, A.; Vennestrøm, P. N. R. Solid-State Ion-Exchange of Copper into Zeolites Facilitated by Ammonia at Low Temperature. ACS Catal. 2015, 5, 16-19.

(30) Huang, Y. Y.; LaPierre, R. B.; McHale, W. D. Process for Dispersing or Redispersing a Group VIII Noble Metal Species on a Porous Inorganic Support for Catalysts. EP306170A1, March 8, 1989.

(31) Apelian, M. R.; Fung, A. S.; Hatzikos, G. H.; Kennedy, C. R.; Lee, C. H.; Kiliany, T. R.; Ng, P. K.; Pappal, D. A. Regeneration of Noble Metal Containing Zeolite Catalysts via Partial Removal of Carbonaceous Deposits. US5393717A, February 28, 1995.

(32) Okumura, K.; Amano, J.; Yasunobu, N.; Niwa, M. X-Ray Absorption Fine Structure Study of the Formation of the Highly Dispersed PdO over ZSM-5 and the Structural Change of Pd Induced by Adsorption of NO. J. Phys. Chem. B 2000, 104, 1050-1057.

(33) Nishihata, Y.; Mizuki, J.; Akao, T.; Tanaka, H.; Uenishi, M.; Kimura, M.; Okamoto, T.; Hamada, N. Self-Regeneration of a PdPerovskite Catalyst for Automotive Emissions Control. Nature 2002, 418, 164-167.

(34) Paredis, K.; Ono, L. K.; Behafarid, F.; Zhang, Z.; Yang, J. C.; Frenkel, A. I.; Cuenya, B. R. Evolution of the Structure and Chemical State of Pd Nanoparticles during the In Situ Catalytic Reduction of NO with $\mathrm{H}_{2}$. J. Am. Chem. Soc. 2011, 133, 13455-13464.

(35) Goodman, E. D.; Johnston-Peck, A. C.; Dietze, E. M.; Wrasman, C. J.; Hoffman, A. S.; Abild-Pedersen, F.; Bare, S. R.; Plessow, P. N.; Cargnello, M. Catalyst Deactivation via Decomposition into Single Atoms and the Role of Metal Loading. Nat. Catal. 2019, 2, 748-755.

(36) Jing, Y.; Cai, Z.; Liu, C.; Toyao, T.; Maeno, Z.; Asakura, H.; Hiwasa, S.; Nagaoka, S.; Kondoh, H.; Shimizu, K. Promotional Effect of $\mathrm{La}$ in the Three-Way Catalysis of La-Loaded $\mathrm{Al}_{2} \mathrm{O}_{3}$-Supported Pd Catalysts $\left(\mathrm{Pd} / \mathrm{La} / \mathrm{Al}_{2} \mathrm{O}_{3}\right)$. ACS Catal. 2020, 10, 1010-1023.

(37) Yu, Q.; Chen, X.; Bhat, A.; Tang, X.; Yi, H.; Lin, X.; Schwank, J. W. Activation of Passive NOx Adsorbers by Pretreatment with Reaction Gas Mixture. Chem. Eng. J. 2020, 399, 125727.

(38) Ryou, Y. S.; Lee, J.; Lee, H.; Kim, C. H.; Kim, D. H. Effect of Various Activation Conditions on the Low Temperature NO Adsorption Performance of $\mathrm{Pd} / \mathrm{SSZ}-13$ Passive NOx Adsorber. Catal. Today 2019, 320, 175-180.

(39) Baba, T.; Komatsu, N.; Sawada, H.; Yamaguchi, Y.; Takahashi, T.; Sugisawa, H.; Ono, Y. O. $1 \mathrm{H}$ Magic Angle Spinning NMR Evidence for Dissociative Adsorption of Hydrogen on $\mathrm{Ag}^{+}$-Exchanged A- and Y-Zeolites. Langmuir 1999, 15, 7894-7896.

(40) Khivantsev, K.; Jaegers, N. R.; Kovarik, L.; Hanson, J. C.; Tao, F.; Tang, Y.; Zhang, X.; Koleva, I. Z.; Aleksandrov, H. A.; Vayssilov, G. N.; Wang, Y.; Gao, F.; Szanyi, J. Achieving Atomic Dispersion of Highly Loaded Transition Metals in Small-Pore Zeolite SSZ-13: High-Capacity and High-Efficiency Low-Temperature CO and Passive $\mathrm{NO}_{\mathrm{x}}$ Adsorbers. Angew. Chem., Int. Ed. 2018, 57, 1667216677.

(41) Dusselier, M.; Davis, M. E. Small-Pore Zeolites: Synthesis and Catalysis. Chem. Rev. 2018, 118, 5265-5329.
(42) Beale, A. M.; Gao, F.; Lezcano-Gonzalez, I.; Peden, C. H. F.; Szanyi, J. Recent Advances in Automotive Catalysis for $\mathrm{NO}_{\mathrm{x}}$ Emission Control by Small-Pore Microporous Materials. Chem. Soc. Rev. 2015, 44, 7371-7405.

(43) Schmieg, S. J.; Oh, S. H.; Kim, C. H.; Brown, D. B.; Lee, J. H.; Peden, C. H. F.; Kim, D. H. Thermal Durability of Cu-CHA $\mathrm{NH}_{3}^{-}$ SCR Catalysts for Diesel $\mathrm{NO}_{\mathrm{x}}$ Reduction. Catal. Today 2012, 184, 252-261.

(44) Deka, U.; Lezcano-Gonzalez, I.; Weckhuysen, B. M.; Beale, A. M. Local Environment and Nature of $\mathrm{Cu}$ Active Sites in Zeolite-Based Catalysts for the Selective Catalytic Reduction of $\mathrm{NO}_{\mathrm{x}}$. ACS Catal. 2013, 3, 413-427.

(45) Chen, H.-Y.; Mulla, S.; Weigert, E.; Camm, K.; Ballinger, T.; Cox, J.; Blakeman, P. Cold Start Concept $\left(\mathrm{CSC}^{\mathrm{TM}}\right)$ : A Novel Catalyst for Cold Start Emission Control. SAE Int. J. Fuels Lubr. 2013, 6, 372381

(46) Lee, J.; Theis, J. R.; Kyriakidou, E. A. Vehicle Emissions Trapping Materials: Successes, Challenges, and the Path Forward. Appl. Catal., B 2019, 243, 397-414.

(47) Khivantsev, K.; Jaegers, N. R.; Kovarik, L.; Prodinger, S.; Derewinski, M. A.; Wang, Y.; Gao, F.; Szanyi, J. Palladium/Beta Zeolite Passive NOx Adsorbers (PNA): Clarification of PNA Chemistry and the Effects of $\mathrm{CO}$ and Zeolite Crystallite Size on PNA Performance. Appl. Catal., A 2019, 569, 141-148.

(48) Zheng, Y.; Kovarik, L.; Engelhard, M. H.; Wang, Y.; Wang, Y.; Gao, F.; Szanyi, J. Low-Temperature Pd/Zeolite Passive $\mathrm{NO}_{x}$ Adsorbers: Structure, Performance, and Adsorption Chemistry. J. Phys. Chem. C 2017, 121, 15793-15803.

(49) Lee, H.; Song, I.; Jeon, S. W.; Kim, D. H. Inter-Particle Migration of $\mathrm{Cu}$ Ions in Physically Mixed Cu-SSZ-13 and H-SSZ-13 Treated by Hydrothermal Aging. React. Chem. Eng. 2019, 4, 10591066.

(50) Kresse, G.; Furthmüller, J. Efficiency of Ab-Initio Total Energy Calculations for Metals and Semiconductors Using a Plane-Wave Basis Set. Comput. Mater. Sci. 1996, 6, 15-50.

(51) Kresse, G.; Furthmüller, J. Efficient Iterative Schemes for Ab Initio Total-Energy Calculations Using a Plane-Wave Basis Set. Phys. Rev. B: Condens. Matter Mater. Phys. 1996, 54, 11169-11186.

(52) Joly, Y. X-Ray Absorption Near-Edge Structure Calculations beyond the Muffin-Tin Approximation. Phys. Rev. B: Condens. Matter Mater. Phys. 2001, 63, 125120.

(53) Bunău, O.; Joly, Y. Self-Consistent Aspects of X-Ray Absorption Calculations. J. Phys.: Condens. Matter 2009, 21, 345501.

(54) Khivantsev, K.; Jaegers, N. R.; Koleva, I. Z.; Aleksandrov, H. A.; Kovarik, L.; Engelhard, M.; Gao, F.; Wang, Y.; Vayssilov, G. N.; Szanyi, J. Stabilization of Super Electrophilic $\mathrm{Pd}^{2+}$ Cations in SmallPore SSZ-13 Zeolite. J. Phys. Chem. C 2020, 124, 309.

(55) Chakarova, K.; Ivanova, E.; Hadjiivanov, K.; Klissurski, D.; Knözinger, H. Co-ordination Chemistry of Palladium Cations in PdH-ZSM-5 as Revealed by FTIR Spectra of Adsorbed and CoAdsorbed Probe Molecules (CO and NO). Phys. Chem. Chem. Phys. 2004, 6, 3702-3709.

(56) Khivantsev, K.; Gao, F.; Kovarik, L.; Wang, Y.; Szanyi, J. Molecular Level Understanding of How Oxygen and Carbon Monoxide Improve NOx Storage in Palladium/SSZ-13 Passive NOx Adsorbers: The Role of $\mathrm{NO}^{+}$and $\mathrm{Pd}(\mathrm{II})(\mathrm{CO})(\mathrm{NO})$ Species. J. Phys. Chem. C 2018, 122, 10820-10827.

(57) Niwa, M.; Katada, N. Combined Method of Ammonia IRMSTPD Experiment and DFT Calculation to Characterize Zeolite Acidity. J. Jpn. Pet. Inst. 2009, 52, 172-179.

(58) Yuan, E. L.; Slaughter, J. I.; Koerner, W. E.; Daniels, F. Kinetics of the Decomposition of Nitric Oxide in the Range $700-1800{ }^{\circ} \mathrm{C}$. J. Phys. Chem. 1959, 63, 952-956.

(59) Reuter, K.; Scheffler, M. Composition, Structure, and Stability of $\mathrm{RuO}_{2}(110)$ as a Function of Oxygen Pressure. Phys. Rev. B Condens. Matter Mater. Phys. 2001, 65, No. 035406.

(60) Li, G.; Pidko, E. A.; van Santen, R. A.; Li, C.; Hensen, E. J. M. M. Stability of Extraframework Iron-Containing Complexes in ZSM-5 Zeolite. J. Phys. Chem. C 2013, 117, 413-426. 
(61) Yasumura, S.; Huang, M.; Wu, X.; Liu, C.; Toyao, T.; Maeno, Z.; Shimizu, K. A CHA Zeolite Supported Ga-Oxo Cluster for Partial Oxidation of $\mathrm{CH}_{4}$ at Room Temperature. Catal. Today 2020, 352, $118-126$.

(62) Moc, J.; Musaev, D. G.; Morokuma, K. Zeolite-Supported Palladium Tetramer and Its Reactivity toward $\mathrm{H}_{2}$ Molecules: Computational Studies. J. Phys. Chem. A 2008, 112, 5973-5983.

(63) Begum, P.; Gogoi, P.; Mishra, B. K.; Deka, R. C. Theoretical Insight of Nitric Oxide Adsorption on Neutral and Charged Pdn ( $\mathrm{n}=$ 1-5) Clusters. Int. J. Quantum Chem. 2015, 115, 837-845.

(64) Goldsmith, B. R.; Sanderson, E. D.; Ouyang, R.; Li, W. X. COand NO-Induced Disintegration and Redispersion of Three-Way Catalysts Rhodium, Palladium, and Platinum: An Ab Initio Thermodynamics Study. J. Phys. Chem. C 2014, 118, 9588-9597.

(65) Posada-Borbón, A.; Heard, C. J.; Grönbeck, H. Cluster Size Effects in Ethylene Hydrogenation over Palladium. J. Phys. Chem. C 2017, 121, 10870-10875.

(66) Chen, L.; Jansson, J.; Skoglundh, M.; Grönbeck, H. Mechanism for Solid-State Ion Exchange of $\mathrm{Cu}^{+}$into Zeolites. J. Phys. Chem. C 2016, 120, 29182-29189.

(67) Loffreda, D.; Simon, D.; Sautet, P. Structure Sensitivity for NO Dissociation on Palladium and Rhodium Surfaces. J. Catal. 2003, 213, 211-225.

(68) Rainer, D. R.; Koranne, M.; Vesecky, S. M.; Goodman, D. W. $\mathrm{CO}+\mathrm{O}_{2}$ and $\mathrm{CO}+\mathrm{NO}$ Reactions over $\mathrm{Pd} / \mathrm{Al}_{2} \mathrm{O}_{3}$ Catalysts. J. Phys. Chem. B 1997, 101, 10769-10774. 